\title{
A ILUMINAÇÃO NO CHALET DO ESTORIL AO TEMPO DA RAINHA
}

\section{MARIA PIA}

The lighting in the Estoril Chalet at the time of Queen D. Maria Pia

António Cota Fevereiro 


\section{Resumo}

No ano de 2018 publicamos a primeira obra dedicada à iluminação da Casa Real, onde disponibilizamos documentação referente às obras, à encomenda de projetos de arquitetura e à aquisição de luminária pela rainha D. Maria Pia para o seu Chalet do Estoril. Nesse mesmo ano tivemos acesso ao interior do edifício onde verificamos a possível colocação das peças para iluminação. Suposição corroborada pelo cotejamento com o Inventário do Real Chalet Estoril, que nos permitiu entender como estas peças foram criteriosamente escolhidas para uma determinada decoração. São estas novas reflexões e a realização de duas plantas dos pisos principais, ao tempo da monarquia, que aqui damos a conhecer.

Palavras-chave: Família Real Portuguesa, Arquitetura de veraneio, Artes Decorativas, Atelier, Luz

\section{Abstract}

In 2018, we published the first work concerning the Portuguese Royal Court lighting. Where we gathered information regarding Queen Maria Pia order of ironstone works, architectural projects and the purchase of lighting fixtures for her Chalet of Estoril. During that same year, we had access to the interior of the building and realized how those lighting fixtures might have been placed. This assumption was confirmed when we collated the Inventário do Real Chalet Estoril (Royal Chalet Estoril Inventory). Which, allowed us to understand how those pieces were carefully chosen for a specific decoration. What we present here is these new considerations and the creation of the two main floor plans at the time of the monarchy.

Key words: Portuguese Royal Family, Seaside Architecture, Decorative Arts, Studio, Light 


\section{INTRODUÇÃO}

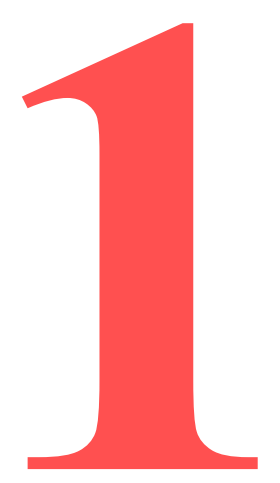

No ano de 1893 a rainha D. Maria Pia (1847-1911) adquiriu o Chalet Longa Vista no Monte Estoril, construção sobranceira com uma vista privilegiada sobre o mar e o horizonte que decerto a terá influenciado, ficando então conhecido como Chalet ou Paço do Estoril. Para o adaptar ao protocolo, embora fosse uma residência de veraneio, a monarca ordenou obras no seu interior de forma a criar determinados espaços com uma função específica, além de criar diferentes níveis de privacidade. Nesta campanha de obras construiu-se um volume adossado para comportar a nova sala de jantar.

No seu interior mandou colocou mobiliário de acordo com a sua qualidade nas salas, nos aposentos da família real, nos aposentos da corte, nos dos empregados e nas áreas de serviço. Este reflete, em parte, o gosto dominante na década de 90 do século XIX em que se privilegiou a assimetria na criação de espaços propícios à sociabilidade, ao conforto, à privacidade e à funcionalidade. O mesmo critério selectivo estendeu-se à luminária e que de acordo com a sua escala, desenho e função foi colocada no mobiliário, na superfície parietal e no tecto. Esta reflete as novas tipologias, os novos meios de iluminação e os novos quebra-luzes em voga adquiridos pela rainha nas lojas mais selectas, cujo conteúdo é aqui revelado e enquadrado na sua época. 
Ao longo do texto usaram-se as seguintes siglas: PNA é referente ao Palácio Nacional da Ajuda; PNP é Palácio Nacional da Pena; PNM Palácio Nacional de Mafra; PNS refere-se ao Palácio Nacional de Sintra e MNAA ao Museu Nacional de Arte Antiga, as quais aparecem conjuntamente com números de inventário de peças que fazem parte do acervo destas instituições. 


\section{AS TENDÊNCIAS ESTILÍSTICAS NA DÉCADA DE 80 DO SÉCULO XIX}

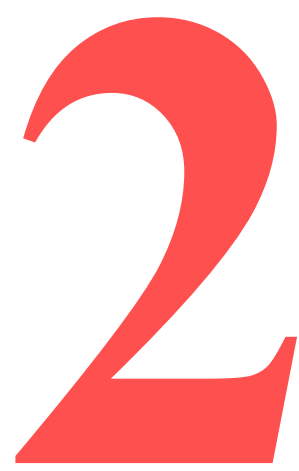

O desenvolvimento de novos meios de iluminação para óleo vegetal, no final do século XVIII em França, despoletou o seu consumo pela burguesia emergente na primeira metade do século XIX. A cidade de Paris tornou-se assim no maior centro produtor mundial e exportador de candeeiros, sobretudo dos do tipo Carcel e modérateur ${ }^{1}$. As principais fábricas foram: Carcel; Gagneau; Gotten; Hadrot; Joseph Schlossmacher (uma das maiores e com loja em Londres); Levavasseur Fréres e Noël Bosselut, entre outras. O candeeiro foi assim vantajosamente empregue em mesas, apliques, candelabros, fogões de sala e em lustres, intensificando assim a luminosidade de determinado espaço interior ou exterior, integrado com a arquitetura e a decoração.

O gosto pela cultura grega e romana dominou a produção parisiense de meados do século, deliberadamente incentivada pelo imperador Napoléon III de França (1808-1873), prestando assim homenagem a seu tio o imperador Napoléon I (1769-1821). A par destas tendências também houve um interesse pela época egípcia, pela da Renascença e pela cultura chinesa e árabe. Foi neste período que os prussianos Heinrich Otto Emil Wild (1826-1896) e

\footnotetext{
${ }^{1} \mathrm{O}$ candeeiro Carcel foi inventado em 1800 pelo relojoeiro francês Bernard Guillaume Carcel (1750-1818), também é designado como de relojoeiro, de maquinismo ou mecânico. O modérateur foi patenteado em 1836 pelo engenheiro francês Charles-Louis-Felix Franchot (1809-1881) e designado, em Portugal, como de bomba na documentação de época.
} 
Friedrich Wilhelm Wessel (c.1830-1898)² foram operários, em 1853, na Nö̈l Bosselut e onde aprenderam o processo de fabricar modérateurs. Com o conhecimento adquirido foram para Berlim onde fundaram em 1855 a fábrica Wild \& Wessel. No início a produção foi claramente dominada pela estética francesa no fabrico dos modérateurs, mas gradualmente evoluíram para formas angulosas e inovadoras. Ao mesmo tempo, investiram no fabrico de queimadores e candeeiros para petróleo, tornando-os assim mais acessíveis em comparação com os anteriores. Começaram a produzir candeeiros em quantidade onde se mesclaram estilizações românicas, góticas, renascentistas, maneiristas e barrocas inspiradas em peças de ourivesaria germânica e italiana. Efetivamente a Wild \& Wessel definiu um carácter germânico a este tipo de peças. Todavia no final da década de 80 do século XIX a fábrica embarcou no gosto pela época da Renascença Germânica, com características tardo-góticas, então em voga na Alemanha. As peças produzidas são geralmente em ferro forjado com volutas, espirais, linhas curvilíneas e motivos padronizados pintadas de preto fosco. Para contrastar cromaticamente aplicaram ornatos em latão e cobre polidos. A Wild \& Wessel foi a mais prestigiante fábrica de luminária alemã e influenciou a concorrente austríaca Rudolph Ditmar.

As cidades de Berlim e de Viena tornaram-se nos principais centros produtores europeus de luminária, assim como a de Birmingham no Reino Unido. Tal facto deve-se ao aperfeiçoamento dos queimadores para petróleo com maior intensidade de luz, além de serem de fácil manutenção e o combustível ser mais acessível.

Após a guerra franco-prussiana a cidade de Paris perdeu parte da sua relevância. Com o aumento da procura de queimadores para petróleo os fabricantes e os retalhistas franceses importaram estes em quantidades consideráveis, como por exemplo a Gagneau que empregou exemplares da Wild \& Wessel e da Evered \& . $^{\circ}$.

\footnotetext{
${ }^{2}$ Ambos nasceram em Schweidnitz na Silésia Prussiana. A localidade chama-se nos dias de hoje Świdnica, após ter passado de novo para a Polónia após a Segunda Grande Guerra (1939-1945). Queremos agradecer ao historiador arménio Ara Kebapcioglu os dados biográficos dos fundadores da Wild \& Wessel.
} 
A produção parisiense gradualmente caminhou para o gosto pela época da Renascença e dos monarcas Louis XV (1710-1774) e Louis XVI (17541793), vincando assim o seu passado prestigiante e cultural após a derrota contra a Prússia. Com efeito a Gagneau neste período impôs-se como uma das mais selectas do seu género, alicerçada na metalística de grande qualidade empregues nos seus produtos.

Na mesma época houve um interesse pela louça de Delft e as fábricas empregaram cópias em variadas soluções. Por um lado, temos uma produção cuidada e pintada à mão, mas a grande maioria foi produzida em faiança decorada por decalques. A fraca qualidade da aplicação destes motivos é obliterada pelo elevado efeito decorativo, realçado pela eterna combinação perfeita do azul sobre fundo branco ${ }^{3}$.

São estas as tendências estilísticas em voga no início da década de noventa na criação de luminária, patente nas peças adquiridas pela rainha D. Maria Pia em 1893 na cidade de Paris, na de Roma e na de Turim.

${ }^{3}$ A informação desenvolvida neste texto foi publicada em 2019 nas Actas do V Colóquio Internacional, A Casa Senhorial: Anatomia dos Interiores (Fevereiro, 2019: 363-388). 


\section{AS NOVAS}

\section{TIPOLOGIAS DE LUMINÁRIA E OS QUEBRA-LUZES}
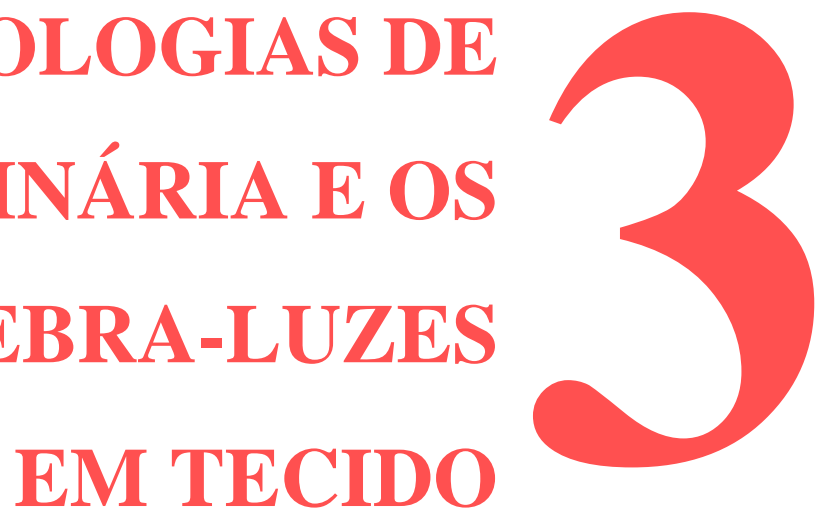

Na década de 80 do século XIX apareceram no mercado novas tipologias de luminária. A primeira foram os candeeiros de pé alto inventados nos Estados Unidos da América para serem colocados ao lado de pianos. São estruturas metálicas com uma haste concêntrica elevatória até a uma determinada altura, presa por um mecanismo ou mola, com um candeeiro amovível no topo. A estas foram adicionados tampos e também passaram a ladear mobiliário de assento nas salas de estar, nas de fumo e nos gabinetes, marcando assim uma presença vertical. A segunda tipologia é a Lampe Bijou ou Babylampe, como se designa em alemão, e é um candeeiro de pequenas dimensões lançado em França. O público feminino adorou e utilizavam-se nas salas de estar, nos gabinetes, nos boudoirs e nos quartos de cama. A terceira são os candeeiros de coluna inventados no Reino Unido e inspirados na cultura clássica e nos motivos arquitetónicos. Foram exportados para França e para a Alemanha, entre outros países, onde depois foram produzidos.

Nestes candeeiros foi geralmente utilizado um novo tipo de quebra-luz feito a partir de uma armação metálica revestida a seda ou a papel, embelezado com flores artificiais, fitas, rendas e outros enfeites. Estes pousam em suportes específicos assentes nas galerias dos queimadores e noutros que passam através das chaminés. A luz maviosa e vaporosa destes quebra-luzes, os contrastes dos motivos das rendas e dos elementos decorativos tiveram um 
sucesso extraordinário, tendo sido também colocados em lâmpadas elétricas e em velas com os respetivos suportes.

Fig. 1 - Pintura intitulada Choix de bijoux sous la lampe da autoria de Marcel Rieder (1862-1942), 1895 a 1910, em que duas senhoras estão em frente a um espelho com um candeeiro para petróleo de coluna aceso e quebra-luz em tecido ou papel. Coleção particular. Imagem sob domínio público.

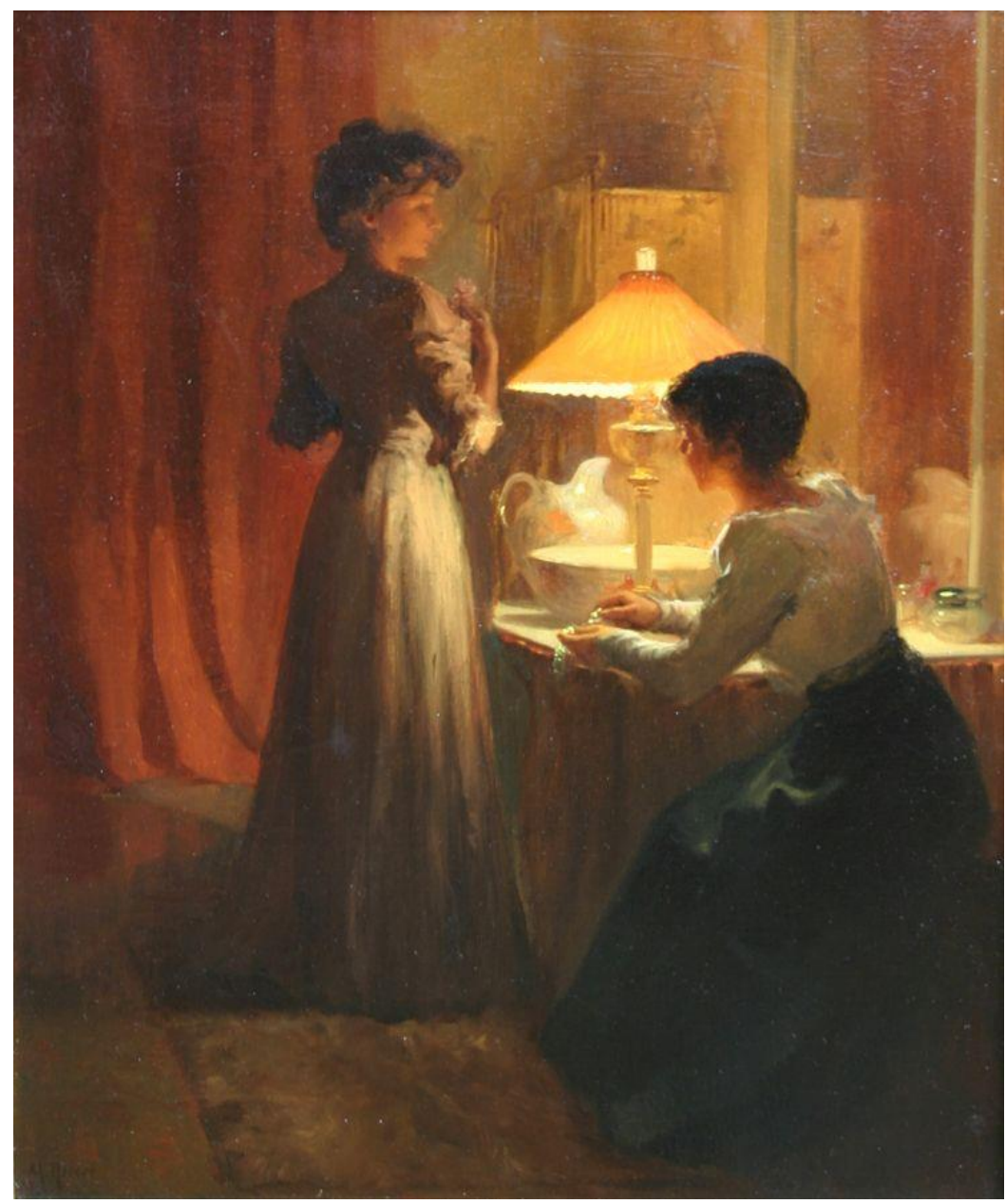

O uso das velas nas salas de jantar com quebra-luzes de tecido ou de papel tiveram um grande sucesso na composição de mesas em salas de jantar, nomeadamente em várias soluções propostas pela obra Mrs Beeton's Book of Household Management ${ }^{4}$. A família real portuguesa aderiu a este gosto, como podemos observar na Sala de Jantar do Paço das Necessidades os

\footnotetext{
${ }^{4}$ Obra publicada em 1861 da autoria da escritora inglesa Isabella Mary Beeton (1836-1865). As edições posteriores, por exemplo a de 1907, foram aumentadas com várias ilustrações coloridas e novos capítulos.
} 
candelabros da Baixela Germain com suportes metálicos e abat-jours de papel sobre as velas ${ }^{5}$.

As melhorias entretanto implementadas nas lâmpadas elétricas, a partir de 1879, pelo célebre inventor americano Thomas Alva Edison (1847-1931) permitiu que ficassem acesas ininterruptamente por várias horas. A incidência de luz sobre uma determinada superfície podia ser assim regulada livremente, sem a condicionante de ter um reservatório. As enormes vantagens desta iluminação, sem manutenção diária e limpeza dos mecanismos, despoletou o seu consumo e foi empregue em candeeiros de mesa, de teto e de parede. Neste período e até à Primeira Grande Guerra (1914-1918) era comum coexistirem diversas fontes de iluminação no mesmo espaço, conforme podemos observar nos interiores do palácio dos marqueses de Linares em Madrid, onde três salas eram alumiadas por candeeiros para petróleo, modérateurs, velas e lâmpadas elétricas (Monte-Cristo e Franzen y Nisser, 1898: 43-45).

No final da década de 80 os castiçais, as serpentinas, as palmatórias e as bouillottes $^{6}$, entre outras tipologias, setecentistas e da primeira metade do século XIX para velas foram copiadas para a electricidade ${ }^{7}$. Nestas utilizaram-se velas falsas em vidro ou em cerâmica, para camuflarem a passagem dos fios elétricos, ou casquilhos em sua substituição. Os quebraluzes eram em tecido, em folha pintada ou em vidro consoante a finalidade.

\footnotetext{
${ }^{5}$ O Arquivo Fotográfico da Câmara Municipal de Lisboa conserva dois negativos, de autor desconhecido, da Sala de Jantar com a referida baixela. As cotas são LSM000016 e LSM000039.

${ }^{6}$ Veja-se por exemplo uma bouillotte para velas no estúdio/escritório do imperador Napoléon I de França (1769-1821) nas Tuileries do Palácio do Louvre, representada em 1812 pelo pintor francês Jacques-Louis David (1748-1825). A tela pertence ao acervo da National Gallery of Art em Washington, com o número de inventário: 1961.9.15.

7 Temos vindo a verificar que nas instituições museológicas e antiquariato nacional e internacional classificam este tipo de peças como sendo do século XVIII, quando são cópias da segunda metade do século XIX e início do XX de origem adaptadas para a eletricidade.
} 


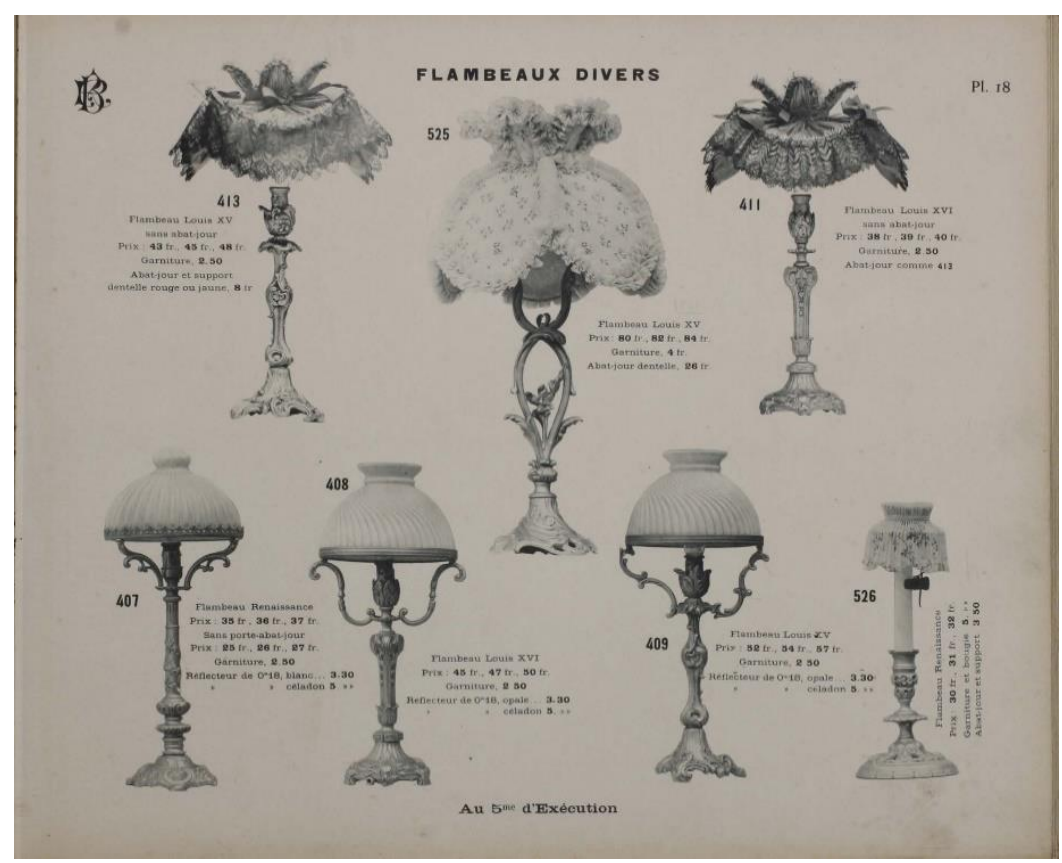

Fig. 2 - Diversos flambeaux elétricos com quebra-luzes de seda/renda e de vidro (Beziel \& Ribot, 19001910: 18). "https://www.CMoG.org".

Parte destas tipologias foram adquiridas pela rainha D. Maria Pia nas compras efetuadas nas duas capitais europeias referidas. 


\section{A AQUISIÇÃO DE LUMINÁRIA EM} 1893

A luminária adquirida em 1893 é a mais extensa e estilisticamente coerente efetuada, até à data e segundo a investigação encetada por nós, pela rainha D. Maria Pia.

Na cidade de Paris a monarca adquiriu as seguintes peças:

- no dia 30 de junho e 25 de julho na $F$. Barbedienne 1 relógio e 2 serpentinas cada uma para 7 velas Louis $X V, 4$ castiças com console e 4 com coquelle tudo em bronze dourado (PNA, inv. 2386 a 2389 e 4093 a 4096) (ANTT, cx. 7008) (APNA, 1911: 1326v)

- no dia 7 de julho na Leuchars \& Son comprou 1 flambeau elétrico com abatjour de seda verde e 1 écran para candeeiro (ANTT, cx. 7008) (APNA, 1912: 3100v-3101);

- no dia 8 de setembro na Maison Gagneau comprou peças ao gosto Louis XV e que constam de 1 lustre de suspensão elétrico de 17 lumes para sala de jantar, 4 apliques de paredes elétricos para 3 lumes cada, 1 lustre elétrico para 3 lumes com flores de cristal e 1 ovo, 1 lustre elétrico para 7 lumes com flores

\footnotetext{
${ }^{8}$ Também adquiriu a escultura Gloria Victis redução 3/10, da autoria do escultor francês Marius Jean Antonin Mercié (1845-1916) que esteve na Segunda Sala e não foi localizada; uma ânfora com mulher alada em bronze dourado pelo escultor francês Louis-Ernest Barrias (1841-1905) (PNA, inv. 43186) (APNA, 1911: 2197); uma taça em mámore com montagens em bronze dourado (PNA, inv. 42291) e uma pia para água benta, com três crianças no alçado, redução n. 2 pelo escultor francês Louis Kley (18331911) (PNA, inv. 42116).
} 
de cristal, 1 lustre elétrico para 19 lumes, 1 ovo em cristal lapidado elétrico para 1 lume, 1 dita para 4 lumes, 1 flambeau elétrico com escultura de criança e abat-jour de seda rosa velho, 1 bouillotte elétrica para 2 lumes, 1 tocheiro elétrico com globo para 1 lume, 2 candeeiros para petróleo com peças em faiança fundo creme e flores polícromas, queimadores Duplex ingleses da Evered e globos Baccarat. No gosto Louis XIV escolheu 1 lanterna elétrica com coroa para 7 lumes. Ao gosto Louis XVI adquiriu um lustre elétrico com uma figura de criança suspensa para 4 lumes. As restantes peças foram 1 braço elétrico com cristais de Veneza para 1 lume e 2 modérateurs em latão e faiança decorada à maneira de Delft com 2 globos e 2 abat-jours de papel (Fevereiro, 2018: 160 e 183-185);

- no dia 9 de novembro na Maison Boudet adquiriu 1 candeeiro para petróleo Louis $X V$ em prata com relógio incorporado e 3 quebra-luzes, provavelmente em papel e de formato cónico, da autoria do ourives francês Lucien Gaillard (1861-1942) conjuntamente com material para escritório (Fevereiro, 2018: $62)$.

Em Turim adquiriu, no dia 26 de maio, na Janetti Padre \& Figli 1 relógio e 2 candelabros em bronze ao gosto gótico (ANTT, cx. 7008).

Na cidade de Roma a rainha comprou na $R$. Ditmar, no dia 30 de junho, 1 candeeiro polido à antiga com abat-jour amarelo e preto (poderá ser o descrito na Primeira sala e depois nos aposentos do rei); 1 candeeiro para estúdio para 2 lumes; 1 lustre para 5 lumes em preto; 1 dito também para cinco lumes em bronze; 1 candeeiro de pé alto para 3 lumes; 5 tulipas; 4 braços para 2 lumes cada; 1 lamparina da signora para petróleo (lampe bijou), com 6 chaminés e 1 metro de torcida; 1 candeeiro para imagem sacra ${ }^{9}$ e 20 lâmpadas elétricas Edison, entre outros acessórios (Fevereiro, 2018: 182-183) ${ }^{10}$.

\footnotetext{
${ }^{9}$ Peça que levantou certas dúvidas e que poderá ser uma descrita no arrolamento, mas esta tem um queimador para azeite da Gebrüder Brunner (Fevereiro, 2018: 58).

${ }^{10}$ Queremos agradecer à Professor Doutora Teresa Leonor Vale por nos ter ajudado e esclarecido na leitura deste documento.
} 
Estas compras vêm no seguimento de uma propensão já manifestada pela monarca no Palácio da Ajuda, quando mandou redecorar o seu Toucador, à Louis XV, e o seu Atelier, ao gosto gótico, entre 1887 a 1889 (Fevereiro, 2018: 55-57). Indubitavelmente segue a moda vigente e as lojas mais selectas, mas com um intuito muito claro: dispôr de acordo com a escala, desenho e função o seu Chalet do Estoril com a maior parte das peças atrás descritas.

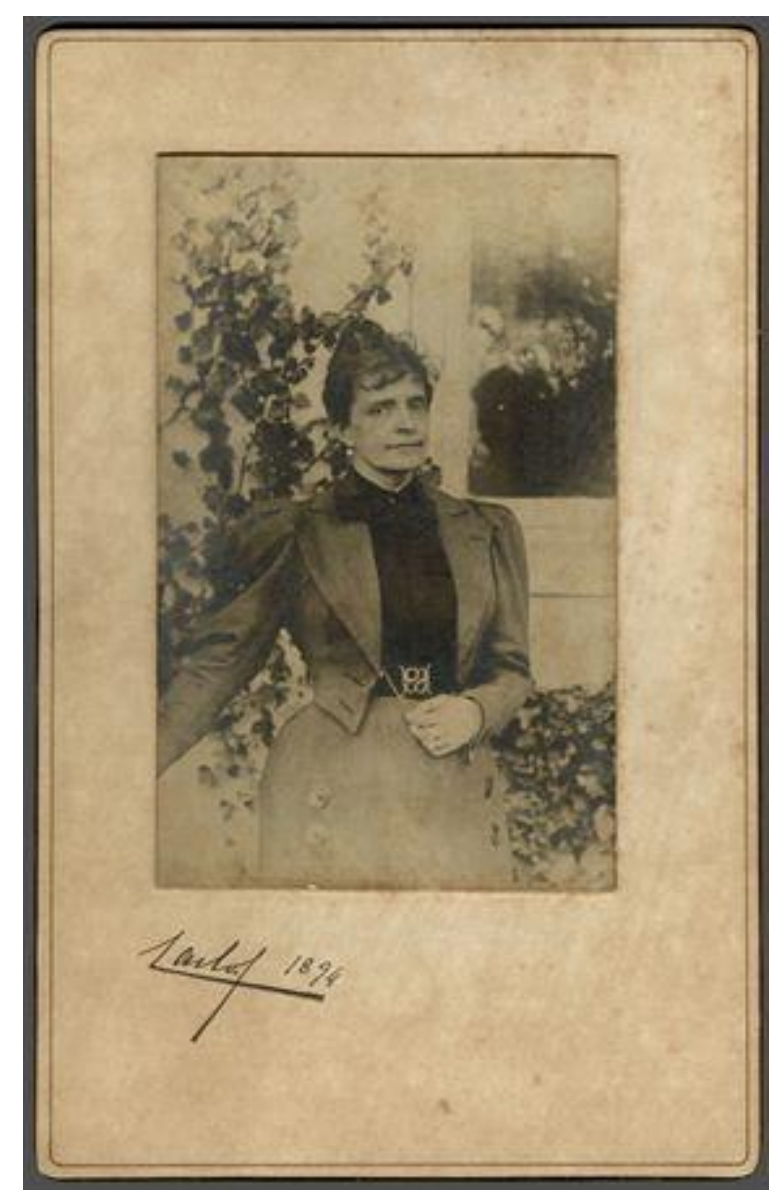

Fig. 3 - Rainha D. Maria Pia, em 1894, no Chalet do Estoril e fotografada pelo filho, o rei D. Carlos (PNA, inv. 62074). Direção-Geral do Património Cultural / Arquivo de Documentação Fotográfica (DGPC/ADF) 


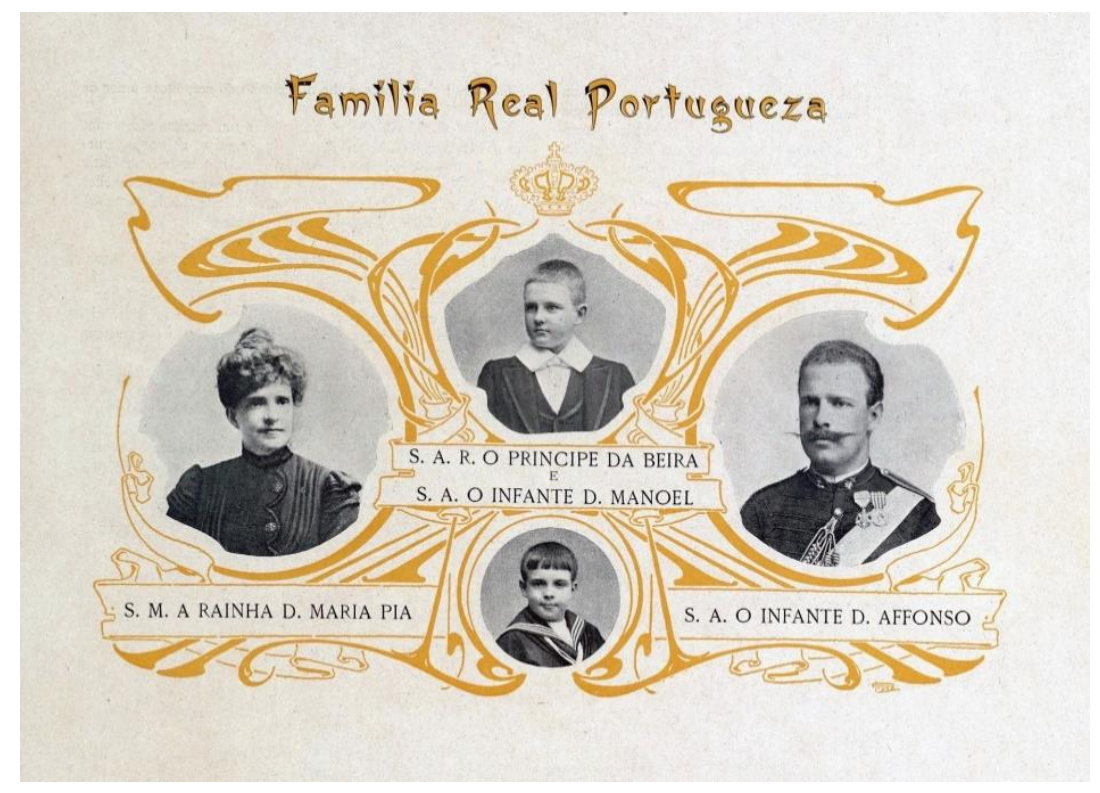

Fig. 4 - Album Açoriano, a rainha D. Maria Pia, o seu filho o infante D. Afonso, o seu neto o príncipe real D. Luís Filipe (1887-1908) e o neto infante D. Manuel, depois rei D. Manuel II. O grafismo Arte Nova é da autoria de Joaquim Guilherme Santos Silva (1871-1948), conhecido pelo pseudónimo Alonso (Album Açoriano, 1903:14). 


\section{O CHALET DO}
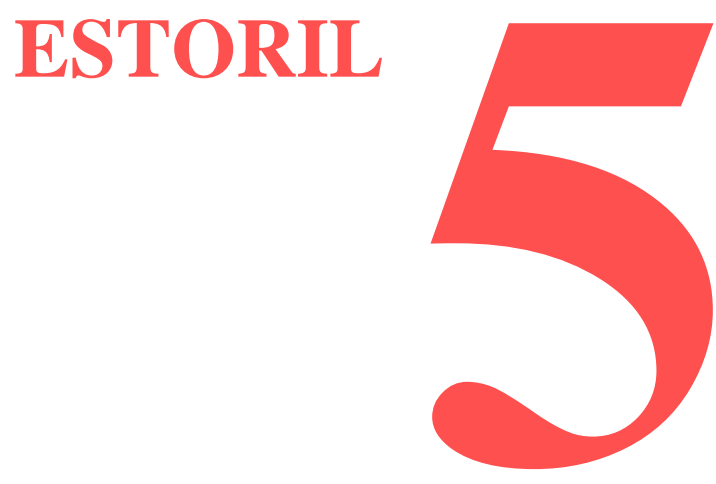

No dia 19 de outubro de 1889 falecia na Cidadela de Cascais o rei D. Luís (1838-1889), sucedendo ao trono o seu filho, o então príncipe real D. Carlos (1863-1908). A rainha viúva D. Maria Pia por causa das más recordações (Andrade, 2009: 219) e, provavelmente, para não importunar o filho e a nora, a rainha D. Amélia (1865-1951), decidiu deixar a Cidadela. A monarca mudou-se para a, então, emergente localidade anexa: o Monte Estoril. Nesta alugou o Chalet Montrose e onde veraneou ${ }^{11}$ até adquirir, em 1893, o Chalet Longa Vista, então pertencente ao negociante João Henrique Ulrick (18501895). Este edifício terá sido mandado construir por ingleses e no arquivo da Câmara Municipal de Cascais não constam quaisquer documentos ou desenhos técnicos sobre o projeto inicial ${ }^{12}$. O desenho arquitetónico é depurado e sóbrio. O traçado classicista da varanda coberta e a sua proporção dignificam o conjunto, salientado assim a sua função e aproveitando as vistas circundantes. A cobertura segue a moda dos lambrequins à maneira suíça, mas desenhados com requinte. As telhas eram de marselha e o uso de outras com cores diferentes criava um motivo padronizado.

\footnotetext{
${ }^{11}$ No Arquivo Fotográfico da Câmara Municipal de Lisboa há um negativo, de autor desconhecido, deste edifício com a bandeira de Portugal hasteada por ocasião da estadia da rainha naquela estância de veraneio. A cota é LSM000909.

12 "Casa da Rainha Dona Maria Pia / Vila Maria Pia," Teresa Leonor Magalhães Vale, Maria Ferreira e Sandra Costa, SIPA - Sistema de Informação para o Património Arquitetónico, Acedido maio, 19, 2020, http://www.monumentos.gov.pt/Site/APP_PagesUser/SIPA.aspx?id=9403.
} 
O projeto é de autor desconhecido e é baseado nas experiências em torno da habitação, europeias e americanas ${ }^{13}$, desenvolvidas no século XIX. A disposição de espaços com uma determinada função e a sua eficaz complementaridade reflete a estratificação social burguesa, baseada na separação dos espaços de estar dos de serviço. Inevitavelmente esta disposição interna reflete-se, em parte, na assimetria dos alçados. De uma maneira geral as cozinhas estão viradas a norte (por causa do acondicionamento dos alimentos em locais frescos e arejados), os espaços de estar a nascente/sul/poente (aproveitando a luz solar) e os de dormir vêm no seguimento da estrutura construtiva do piso inferior. De acordo com estas premissas o projetista aproveitou o declive do terreno e escolheu a extremidade sul para erigir o edifício. Desta forma o piso térreo ficou semienterrado, o principal com vistas sobre o mar e a envolvente, seguido dos restantes com os quartos e o sótão. Esta delineação aproveitou todo o potencial que o terreno teve para oferecer e da qual partiu a distribuição interna inicial:

- Rés-do-chão com vários compartimentos e a cozinha na extremidade norte/poente;

- A caixa de escadas, único acesso vertical no interior ${ }^{14}$, na fachada nascente;

- O primeiro andar tem a entrada principal na fachada nascente, seguida de um vestíbulo, um corredor longitudinal e perpendicular ao anterior, eixo distribuidor principal. Em torno deste eixo em T estão os restantes espaços de estar/receber. As salas principais estão viradas para

\footnotetext{
${ }^{13}$ A relação espaços, zonas e a procura do conforto no lar aperfeiçoou-se durante o século XIX, sobretudo nos países anglo-saxónicos. Nos Estados Unidos da América foi publicado em 1842 a obra A Treatise on Domestic Economy for the Use of Young Ladies at Home and at School, pela pedagoga Catharine Esther Beecher (1800-1878). No Reino Unido o arquiteto Robert Kerr (1823-1904) publica, em 1864, na cidade de Londres a obra The gentleman's house; or, How to plan English residences from the parsonage to the palace. Outro factor decisivo na propagação de soluções arquitetónicas e espaciais inovadoras, foi a publicação periódica americana Godey's Lady's Book, publicada de 1830 a 1878 (Ramos, 2010: 2-72 e 194195).

${ }^{14}$ Nos projetos deste tipo de habitação de veraneio era comum prescindir-se da escadaria de serviço, aproveitando assim mais área para os restantes espaços, como temos vindo verificar nos processos de obra existentes no arquivo da Câmara Municipal de Cascais.
} 
nascente, sul e poente, com uma varanda coberta exterior com vista sobre o mar. A antiga sala de jantar estava virada a norte;

- O segundo e o terceiro andar têm os corredores com largura superior, facilitando assim a circulação e a colocação de mobiliário para arrecadar roupa. Os quartos desta forma tornaram-se mais pequenos e confortáveis;

- Na fachada poente há um volume octogonal e uma escadaria externa do primeiro andar para o jardim.

Este interior manteve-se quase todo inalterado, exceto nos seguintes pontos:

- No fundo do vestíbulo, do lado esquerdo para quem entra, foi colocado um ascensor e a escadaria passou a serviço. $\mathrm{O}$ ascensor deveria ser utilizado pela família real e restante corte, evitando assim o cruzamento nas escadas com o pessoal doméstico;

- A sala de jantar, e a do lado, deram lugar a três novos espaços. Desta forma ficaram, da fachada nascente para a poente, o Quarto do Ajudante de Sua Majestade, a Sala d'entrada e a Sala de espera.

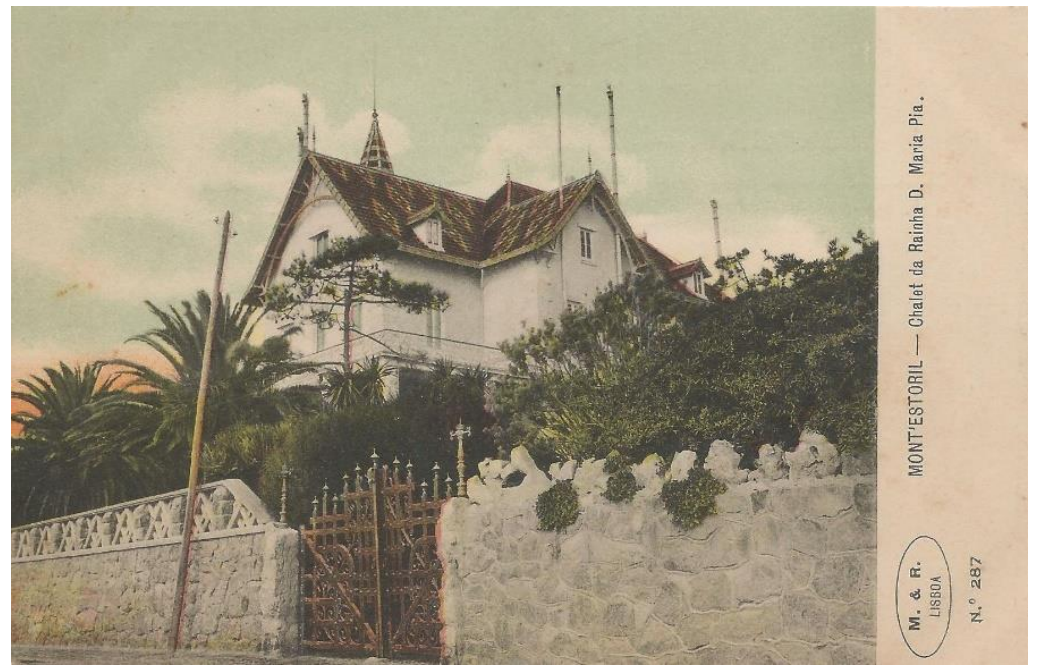

Fig. 5 - Chalet do Estoril. Postal sem data e editado pela M. \& R. Lisboa N. ${ }^{\circ} 287$. Coleção do autor. 
A Sala d'entrada passou assim a ser um espaço entre o público e o privado, para onde se passava para a Sala de espera onde se era recebido. No seguimento desta última foi construída a nova Casa de Jantar, com a cozinha no rés-do-chão, num volume adossado e construído propositadamente para esse fim. O projeto esteve a cargo do arquiteto Luís Caetano Pedro de Ávila $(1832-1904)^{15}$ e segundo “... as indicações e desejos da rainha sr. ${ }^{a}$ D. Maria Pia, ficou de um rigor estranho, nos seus mais minuciosos pormenores, o que bem manifesta a alta competencia e os vastos conhecimentos que da sua grande arte tem Rozendo Carvalheira." (Marques, 1896: 75)

No Palácio da Ajuda foi arrolado, em 1912, um conjunto de desenhos técnicos (APNA, 1912: 2512) e que podem ser os que se encontram hoje no Arquivo Nacional da Torre do Tombo ${ }^{16}$, oferecidos à monarca por Luís Caetano Pedro de Ávila. Da sua leitura depreende-se que o arquiteto deverá ter sido o autor das alterações internas do edifício e da construção do novo volume. O projeto da Casa de Jantar poderá ser da autoria do arquiteto Rosendo Garcia de Araújo Carvalheira (1861-1918), conforme nos relata a imprensa da época.

Por causa desta nova disposição interna a fachada tardoz foi alterada e colocado um toldo em ferro, para resguardar da intempérie quem chegasse. $\mathrm{O}$ reboco exterior simula um aparelho de pedra e que se prolonga para o volume adossado. O desenho arquitetónico remete-nos para as construções análogas francesas, acentuada pelas persianas nas portas janelas e um certo ar mediterrânico.

15 Teve como honorários o valor de 1:700.000 réis. Ao arquiteto Cesare Ianz (c.1862-1896) foram encomendados outros trabalhos e despesas decorrentes, conforme o recibo datado de 16 de fevereiro de 1895, que constam de: dois projectos de ampliação realizados em 1894 no valor de $870 \$ 000 ; 1$ orçamento de 435\$000 em 1894; transportes, jornadas e despesas várias no valor de $95 \$ 000$ nos anos de 1894 e 1895 , o que perfez um total de 1:400\$000 réis (Fevereiro, 2018: 63).

${ }^{16}$ Ver "Plantas da vila no Estoril de Sua Majestade a rainha a senhora D. Maria Pia,", Arquivo Nacional da Torre do Tombo, última modificação fevereiro, 4, 2015, Acedido maio, 19, 2020, https://digitarq.arquivos.pt/details?id=4644229. 
A Casa de Jantar foi decorada à Louis $X V$, com obra de talha em nogueira sobre olho-de-perdiz com ornatos em dourado da autoria de Guilherme Coutinho (1844-?) (Marques, 1896: 75) ${ }^{17}$.

As pinturas ficaram a cargo do artista António Ramalho (1859-1916) e que enveredou pela representação de espécimes botânicos, tendo como fundo o céu azul, nuvens e andorinhas nas paredes e sobre os vãos. Estas pinturas quebram a simetria das boiseries, imbuídas ainda num gosto naturalista e japonizante em voga uns poucos anos antes ${ }^{18}$. No tecto realizou, nos quatro cantos, pinturas com grinaldas de flores, cestos de flores e pombas. Ao centro há um medalhão com ramos floridos, aves e três meninos com fitas cor-derosa unidas a esvoaçarem do centro de onde pendia o lustre, pormenor invulgar e original, assinada pelo artista em 1896. Esta pintura é ladeada pelos escudos da Casa de Bragança e pela de Sabóia, solução afirmativa que a rainha também seguiu no seu Atelier no Paço da Ajuda.

A proporção harmónica deste espaço apoia-se na sua simetria e na delicadeza perene e assimétrica das pinturas, contribuindo assim para um certo dolce far niente que se espera numa estância de veraneio.

Os trabalhos de marcenaria e parquets estiveram a cargo de Frederico Augusto Ribeiro (1853-?), que na mesma altura fez outros trabalhos para o Paço das Necessidades e para a Cidadela em Cascais (Marques, 1896: 75) ${ }^{19}$, entre outros fornecedores ${ }^{20}$.

\footnotetext{
${ }^{17}$ Temos vindo a fazer um levantamento, desde 2010, de projectos de arquitectura e artistas associados na região de Lisboa entre a segunda metade do século XIX e início do XX e só encontramos o nome de Guilherme Coutinho como autor de parte da marcenaria e da talha para o Sanatório de Sant'Anna na Parede. A restante é da autoria de Frederico Augusto Ribeiro. O projecto arquitetónico é da autoria de Rosendo Carvalheira, onde também colaboraram os arquitetos Álvaro Augusto Machado (1874-1944), Manuel Joaquim Norte Júnior (1878-1962), António do Couto de Abreu (1874-1946) e Adolfo António Marques da Silva (1876-1939). (Costa Campos, 1908: 35). No entanto apresentamos aqui, pela primeira vez, dados sobre o entalhador Guilherme Coutinho: nasceu no dia 1 de janeiro de 1844 na freguesia da Sé de Lisboa e filho legítimo de António Joaquim Coutinho e de Antónia Maria dos Mártires Martins; casou no dia 2 de junho de 1867 na freguesia de São José, da mesma cidade onde era morador no Largo da Oliveira n. ${ }^{\circ}$ 7, com Jesuína Adelaide de Carvalho.

${ }^{18} \mathrm{O}$ mesmo género de pinturas, mas com fundo rosa, foram realizadas na Sala de Jantar do infante D. Afonso no andar nobre do Palácio da Ajuda.

${ }^{19}$ Foram de sua autoria o Gabinete ou Quarto do rei D. Carlos no Palácio das Necessidades e a Sala de Jantar na Cidadela de Cascais (remodelada após a morte de D. Luís por vontade do filho) (Fevereiro, 2012: 256-258).

${ }^{20}$ Os fornecedores foram os seguintes: Herrmann (instalações eléctricas); Barbosa \& Costa (mobiliário); Manuel Henrique (cal de Alcabideche); Domingos António Geraldo (cimento, cal, tijolo e saibro); António
} 
A nível de estuques não sabemos quem foi o encarregado, mas os de melhor qualidade encontram-se na Sala d'entrada, na Sala de espera, nos Corredores do $1 .^{\circ}$ Pavimento, na Primeira Sala, na Segunda Sala e na Salinha Oitavada. Estes são na maioria Louis XVI, exceto a Salinha Oitavada que é ao gosto mourisco. Os dos dois primeiros espaços são inegavelmente da campanha de remodelação, mas os restantes não há ainda a certeza se são os de origem. Efetivamente estes estuques levantaram várias questões concernentes às inclinações da rainha D. Maria Pia. Ao longo da sua vida seguiu as últimas tendências estilísticas, embora assimiladas de acordo com o seu próprio gosto e para uma determinada decoração. Cronologicamente estas foram: nos anos 60 e 70 as culturas clássicas e da renascença; na década de 80 o japonismo, a renascença, o gótico e o reinado de Louis XV; nos anos 80 para 90 a renascença germânica e Louis $\mathrm{XV}$; nos anos 90 e início do século XX embarca na Arte Nova e na aquisição de peças depuradas esteticamente ${ }^{21}$. Após a viuvez, e ao fim ao cabo com mais tempo livre dos assuntos de estado, entrega-se com mais afinco à consecução de mobiliário, tecidos, porcelanas ${ }^{22}$, peças decorativas, ourivesaria e demais objectos, na sua grande maioria Louis $X V$. Estes foram elencados aquando do arrolamento judicial, entre $1911 \mathrm{e}$ 1913, no Paço da Ajuda, nomeadamente o mobiliário e já objeto de estudo por Maria do Carmo Rebello de Andrade. Uma parte é da autoria dos ébénistes preferidos da monarca, o italiano Paul Sormani (1817-1877), residente em Paris, e seu filho Paul-Charles Sormani (1848-1926), adquiridos

Francisco da Matoza (lavagens e pintura); Julio Gomes Ferreira \& $C .{ }^{a} L d .{ }^{a}$ (canalizações para água, gás e electricidade); Filtre Chamberland systeme Pasteur (filtros de água); Joaquim Domingos de Oliveira (vidros para vãos); José Moreira Rato \& Filhos (cantaria); Thiago Antonio da Silva \& Ca (ferragens); José Joaquim Ferreira (perfumaria e drogaria); Frederico Collares (vigamente em ferro para a Casa de Jantar); Izidro Soares da Silva Pereira \& C. ${ }^{a}$ (madeira); Antonio Jose Fernandes Jasmim (papelaria); Maison Fontaine Paris; António Moreira Rato \& Filhos (cantaria) e João Felix da Silva (Fevereiro, 2018: 63).

${ }^{21}$ A Família Real Portuguesa e a Arte Nova têm vindo a ser objecto de estudo no decurso da nossa investigação sobre a corrente estética.

${ }^{22}$ No remasnescente espólio de porcelana são significativos os serviços de mesa e bebidas quentes Meissen, copiados e característicos da sua produção setecentista, adquiridos pela rainha no início do século XX. (Reis e Louro, 1987: 25-45). 
para o Paço do Estoril e da Ajuda. Contudo, para este último, adquiriu uma vitrine Louis XVI (PNA, inv. 1662) (Andrade, 2009: 212-213), único exemplar entre quinze de mobiliário atualmente existente destes autores. A mesma diminuta compra por peças Louis XVI é evidente no recibo de 1893 da Gagneau, anteriormente aludido, o que parece indicar que só muito pontualmente a rainha integrou este estilo em determinados espaços. No entanto, o Louis $X V$ é dominante no Chalet do Estoril, conforme iremos abordar em seguida. 


\section{A ILUMINÁRIA}

\section{NO CHALET DO}

ESTORIL

No Inventario do Chalet Real Estoril ${ }^{23}$, realizado entre $1896^{24}$ a 1910 , o (s) arrolante (s) começou (aram) no 1. ${ }^{\circ}$ Pavimento pela Primeira Sala. A maioria do mobiliário Louis $X V$ era composto por de assento, biombo, cadeiras e mesas, conjuntamente com cortinados no mesmo gosto ${ }^{25}$. Havia também mobiliário de assento estofado, um relógio em forma de farol (PNA, inv. $1990)^{26}$, um aquário em porcelana oriental (PNS, inv. PNS111) ${ }^{27}$, mesas, biombos, um armário e o busto do rei Vittorio Emanuele II (1820-1878) pai da monarca, entre outras peças. Esta disposição assimétrica e eclética é característica de finais do século XIX, complementada por plantas em vasos, biombos e outras peças verticais para diferentes enquadramentos e recantos no espaço para estar e conversar, aproveitando assim todo o potencial da

\footnotetext{
${ }^{23}$ Queremos agradecer à conservadora de ourivesaria Teresa Maranhas do Palácio Nacional da Ajuda nos ter disponibilizado o inventário para consulta.

${ }^{24} \mathrm{O}$ serviço de mesa e sobremesa, respetivamente da Haviland e Laviolette, foi adquirido no dia 21 de dezembro de 1896 aos armazéns Grand Dépôt E. Bourgeois em Paris. (Reis e Louro, 1987: 118).

${ }^{25}$ Este tipo de cortinados eram vendidos nos armazéns da Maple \& Co. inspirados na época Louis XIII, XIV, XV e XVI, entre outros de gosto mais moderno (Maple \& Co.,1889: 172-176). Nestes armazéns fornecia-se a família real portuguesa.

${ }^{26}$ Está hoje na Sala de Marmore do Palácio da Ajuda.

${ }^{27}$ Identificado por nós no decurso desta investigação.
} 
varanda coberta exterior e vistas. Sobre o fogão de mármore, com vão exterior ao centro à francesa, estava um relógio e respetivas serpentinas Louis $X V$ em bronze dourado, provavelmente adquiridos em 1893 na $F$. Barbedienne. A restante iluminação era assegurada por: um tocheiro com um globo (APNA, 1911: 668 e 2214); um lustre para 7 lumes e por um candeeiro elétrico de uma figura sobre uma peanha da Gagneau. Havia também dois quebra-luzes de seda: um amarelo com rendas pretas e outro branco e rosa (APNA, sem data: 2-11).

\section{1. ${ }^{\circ}$ Pavimento}

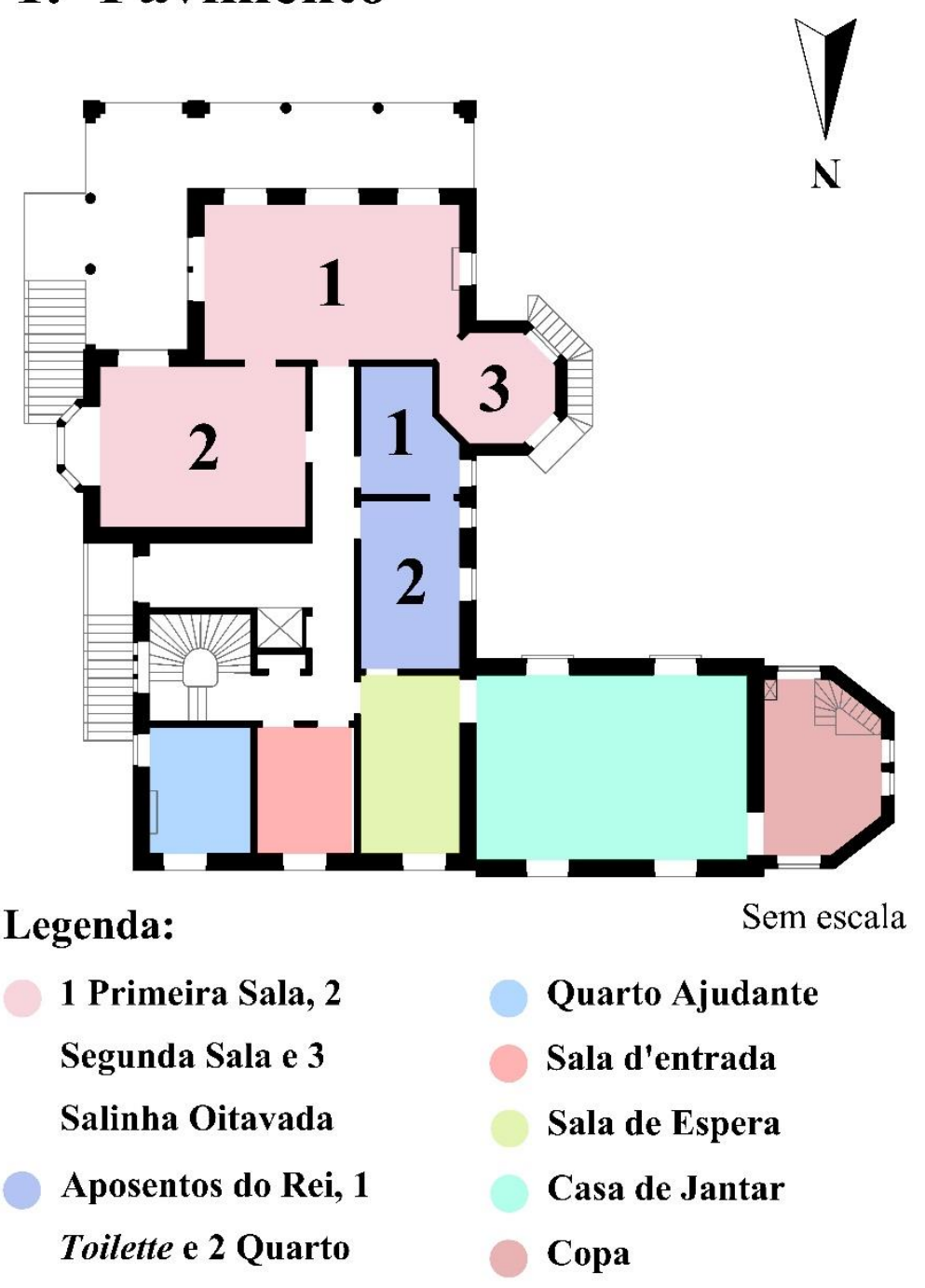

Fig. 6 - Planta do $1 .^{\circ}$ Pavimento realizada pelo autor em formato digital. 


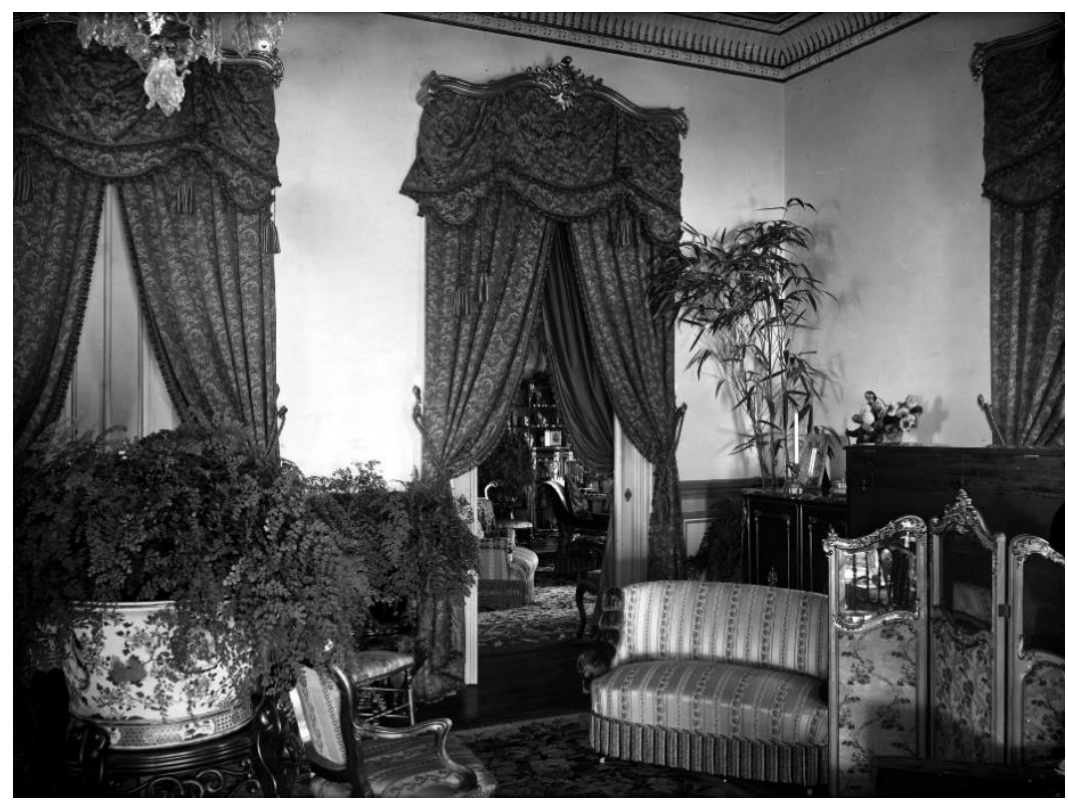

Fig. 7 - Primeira Sala, provavelmente em 1896, fotografada para o artigo de Henrique Marques. Podemos observar o aquário que está hoje no Palácio Nacional de Sintra. Esta fotografia e a da Casa de Jantar foram identificadas por nós no Arquivo da Câmara Municipal de Lisboa. Fotografia de autor desconhecido, sem data. Arquivo da Câmara Municipal de Lisboa, núcleo fotográfico, cota: NEG000291.

A Salinha Oitavada foi decorada com: mobiliário de assento estofado; duas cadeiras Louis $X V$; mesas e uma secretária. Nesta sala havia material para fotografia e um cavalete, o que parece indicar ser um espaço de trabalho. Como iluminação foi descrito um candeeiro elétrico em bronze dourado Louis $X V$ com abat-jour côr de rosa, um lustre no mesmo metal para quatro lumes (APNA, sem data: 12-17). 


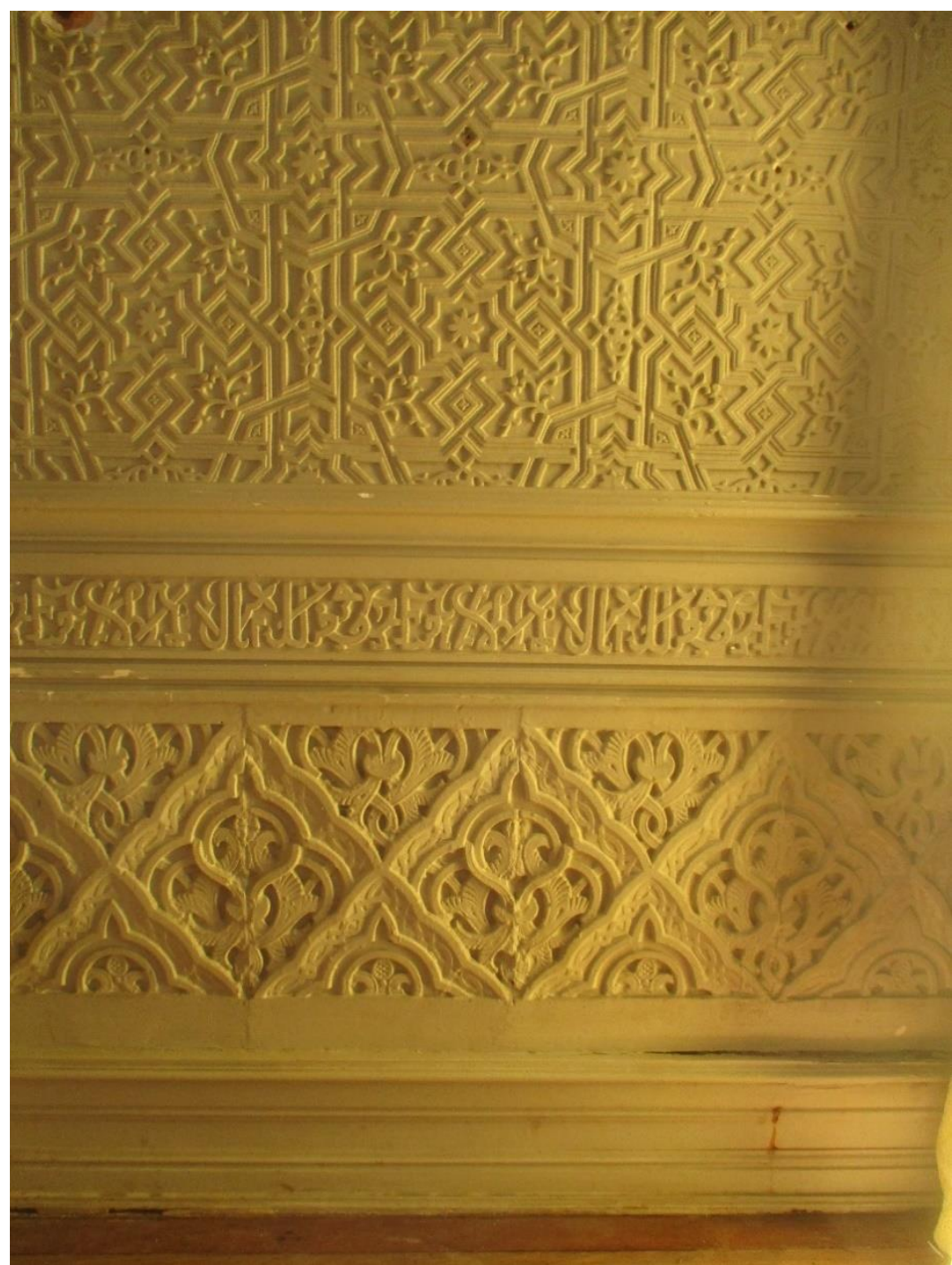

Fig. 8 - Salinha Oitavada, rodapé em madeira, lambril e superfície parietal em estuque, pormenor. Fotografia do autor, 8 de novembro de 2018.

A Segunda Sala continha mobiliário de assento estofado, uma mesa de centro, cadeiras, uma chaise-longue, mesas, um armário envidraçado e um biombo. Ao gosto Louis $X V$ havia três cadeiras, uma mesa, um espelho e uma credência antiga. A nível de luminária era guarnecida com um lustre central para 19 lâmpadas elétricas; dois apliques para 3 lâmpadas cada um nas paredes; um candeeiro de pé alto com abat-jour de seda cor-de-rosa e um anjinho suspenso com duas lâmpadas elétricas. O lustre e os dois apliques parecem ser os adquiridos na Gagneau O de coluna com quebra-luz de seda, aparentemente, poderá ser o da $R$. Ditmar ou os que foram arrolados na Ajuda 
e em $\operatorname{Sintra}^{28}$. Este espaço pode ser considerado mais de trabalho, de escrita e de estar de acordo com a leitura do inventário (APNA, sem data: 18-29).

O vestíbulo e o corredor, descritos como Corredores do $1 .^{\circ}$ Pavimento eram iluminados por uma lanterna para 4 lâmpadas elétricas, provavelmente da Gagneau, e por dois candeeiros para petróleo de parede (APNA, sem data: 30-31) (APNA, 1912: 3395v. a 3396).

Os aposentos do rei D. Carlos, ou de D. Manuel (1889-1932), eram compostos pelo Toilette e pelo Quarto de Sua Magestade El-Rei. No quarto o mobiliário era à época do rei francês Henry II (1519-1559) e tinham luz elétrica (APNA, sem data: 32-39).

O Quarto do Ajudante de S. M. tinha uma tulipa e lâmpada elétrica, mobiliário em pitch-pine e um telefone Herrmann (APNA, sem data: 44-47).

A Sala d'entrada estava mobilada com mobiliário de assento em couro, com ornatos em metal amarelo e uma mesa de centro. Do teto pendia a lanterna Louis XIV da Gagneau (APNA, 1912: 3394v. a 3395). Na Sala de espera optou-se por mobiliário de assento dourado Louis $X V$, uma mesa e um lustre para cinco lâmpadas elétricas com tulipas, provavelmente o adquirido na $R$. Ditmar (APNA, sem data: 48-55).

\footnotetext{
${ }^{28}$ A rainha D. Maria Pia adquiriu em Paris, em 1905, dois candeeiros de pé alto e que chegaram a Lisboa em 1906. O primeiro é francês, Louis XV, bronze dourado, com um queimador Elite para petróleo da Carl Holy de Berlim e tinha um abat-jour de seda rosa (PNA, inv. 2082). O segundo é britânico, para luz elétrica, metal dourado e também tinha um abat-jour cor-de-rosa (PNA, inv. 51101). Ambos foram arrolados no Paço da Ajuda na Sala Azul. Se o descrito no Estoril for o segundo exemplar: o inventário do Chalet poderá ser datado de 1906 a 1910. Na Ajuda tinha um para petróleo da Hinks (PNA, inv. 44262) e outro neste modelo, adaptado em Paris, para um modérateur (PNP, inv. PNP2140). No Paço de Sintra tinha outro descrito para electricidade, mas nas fotografias existentes da Salla dos Cysnes podemos observer que era para petróleo e não foi localizado (Fevereiro, 2018: 72-77).
} 


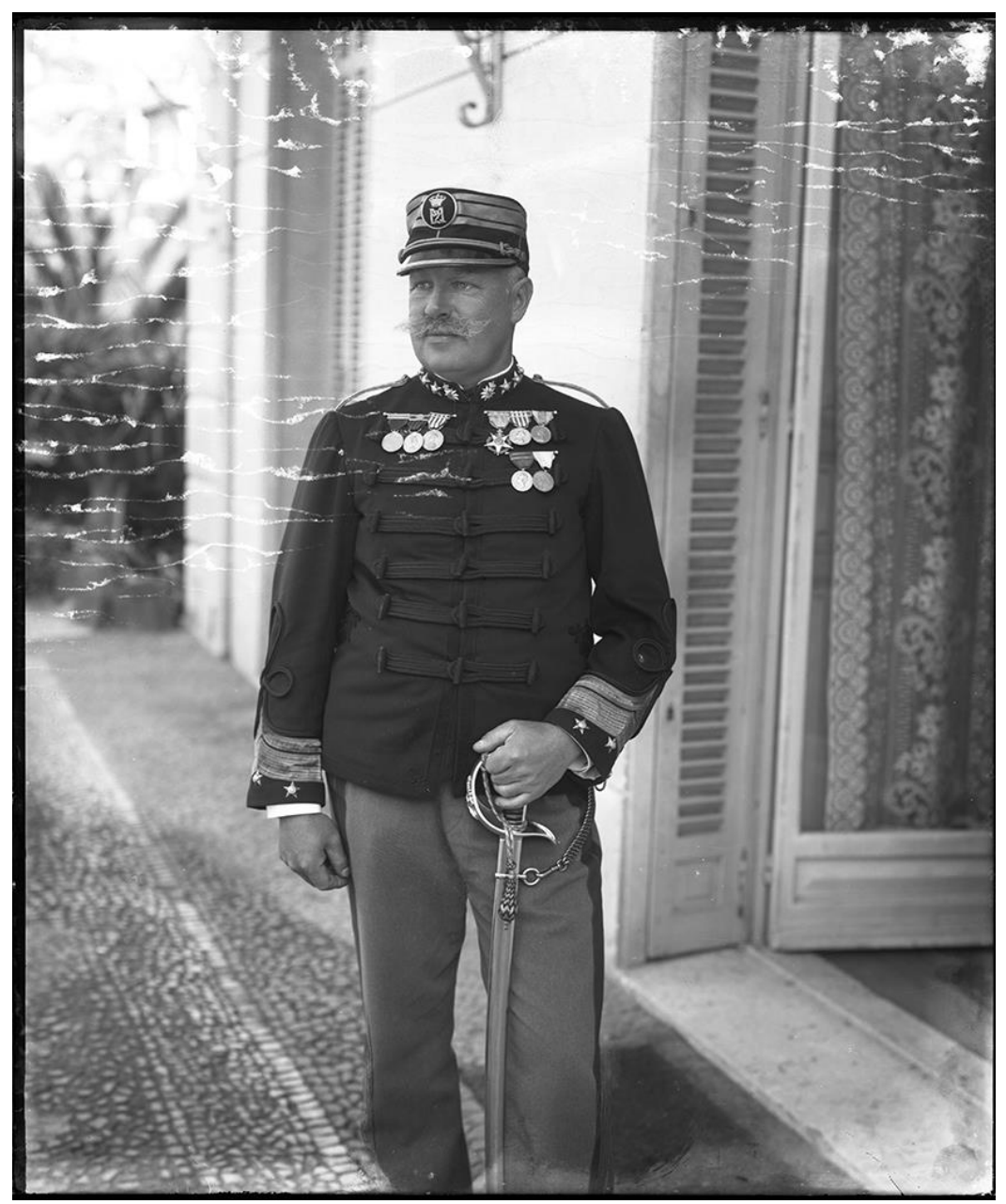

Fig. 9 - Infante D. Afonso fotografado, em 1909, pelo fotógrafo britânico David Knights-Whittome (1876-1943) em frente à porta exterior da Sala d'entrada. The Past on Glass at Sutton Archives, DKW_30452A_Alfonso_L.

Na Casa de Jantar o mobiliário era composto por uma mesa extensível, um trinchante, um guarda-prata, um aparador e 24 cadeiras em couro com o monograma real ao gosto da renascença. Efetivamente as cadeiras assemelham-se às que a rainha encomendou para o Paço da Ajuda, posteriores a 1879, e às do Paço de Sintra encomendadas à parisiense Maison Krieger A. Damon \& Cie. em 1889 (Montesinos, 2019: 87) para as respetivas salas de jantar da época renascentista e maneirista. Temos assim a continuação de um gosto já manifestado nos paços onde residiu, mas, todavia, encomendou um projeto para sala de jantar Louis $X V$ à Maison Krieger em data 
desconhecida ${ }^{29}$. Ao centro pendia o lustre em bronze dourado Louis $X V$, com abat-jour verde ao centro e braços laterais para lâmpadas elétricas da Gagneau $^{30}$. Nos armários foram elencadas quatro serpentinas Christofle cada uma para 4 lumes (PNA, inv. 6429 a 6434 e 451 a 454), quatro em metal prateado cada uma para 3 lumes (PNA, inv. 396 a 397 e 44594 a 44595$)^{31}$ e vinte e oito bobeches. Os serviços em porcelana eram: uma molheira com friso azul da Vista Alegre; um de mesa da mesma proveniência com filetes vermelhos $^{32}$; um dito da mesma manufatura com friso verde ${ }^{33}$; chávenas para chá, café e pequeno-almoço do mesmo fabricante com heras cor-de-rosa ${ }^{34}$;

${ }^{29}$ O Palácio Nacional da Ajuda conserva o projecto da Maison Krieger e que se compõe por: um desenho de duas cadeiras com assentos estofados, uma com espaldar em palhinha e a segunda com o mesmo espaldar, mas estofado no cachaço (PNA, inv. 45161); uma mesa (PNA, inv. 45153); um aparador (PNA, inv. 59516) e os cortinados (PNA, inv. 45160).

${ }^{30} \mathrm{Na}$ fotografia publicada em 1896, de fraca qualidade de impressão, constatamos que o lustre é o mesmo modelo de um no Palácio Nacional de Mafra (PNM, inv. PNM 2017). Tem um abat-jour verde acinzentado, o mesmo número de luzes e todas as características descritas, o que nos levou a assumir que era o exemplar do Chalet do Estoril. Todavia, com a descoberta recente da fotografia da Casa de Jantar constatamos que os quatro cabos de suspensão são diferentes dos que estão em Mafra. Um lustre com todas as características do mesmo que esteve na Casa de Jantar foi o lote 213 do leilão 115, que ocorreu de 13 a 14 de dezembro de 2017, da leiloeira Renascimento em Lisboa.

${ }^{31}$ Foram depois para o Paço da Ajuda e onde foram arroladas na Arrecadação das pratas e louças. Na mesma arrecadação mencionam outro par de serpentinas para 3 lumes cada uma e que podem ser as que atualmente têm os números de inventário 394 e 395 (APNA, 1911: 1175v. e 1344). No Chalet do Estoril a rainha D. Maria Pia tinha, pelo menos, 16 suportes de velas para abat-jours (APNA, 1911: 1315v.)

${ }^{32}$ Não constam no acervo do Palácio Nacional da Ajuda.

${ }^{33}$ Serviço referido em inventários anteriores a 1910, mas, aparentemente, não foi arrolado no Paço da Ajuda.

${ }^{34}$ Ostenta a marca de fabrico Verde grande fogo a pincel usada de 1881 a 1921 . No inventário dizem que são parras e este serviço para bebidas quentes está marcado para o estabelecimento comercial lisboeta Boaventura dos Reis, filho 141 a Rua da Prata 143 Lisboa, foi depois arrolado no Paço da Ajuda (APNA, 1911: 1495v.) (PNA, inv. 19867 a 19942, em cacos 19443 a 19952, 19953 a 19996, em cacos 19997 a 20007 e 20008 a 20056) 
chávenas para café e para chá azuis-escuras de Sèvres ${ }^{35}$; chávenas para café em azul-escuro da francesa Pillivuyt ${ }^{36}$ e parte do serviço do Estoril das francesas Haviland e Laviolette, produzidos na região francesa de Limoges ${ }^{37}$. A policromia destes exemplares como que se enquadra com a restante decoração, pormenor sensível que a rainha demonstrou nos paços onde residiu. Na Copa havia dois candeeiros para petróleo de parede (APNA, sem data: 56-65).

35 Trata-se de um conjunto de chávenas para chá e para almoço adquiridas na manufatura em 1888 pela rainha (PNA, inv. 16767 a 16819, 42513 a 42521, exceto a 42517 que é uma peça Meissen) (APNA, 1911: 1487v. a 1488) (Correia, 2008: 120).

${ }^{36}$ Estas chávenas fazem parte de um serviço de mesa, de sobremesa, de pequeno-almoço, de chá, de chocolate e de café que existe actualmente no acervo do Palácio Nacional da Ajuda (APNA, 1911: 1458 a 1461v.) (PNA, inv. 2450 a 2454, 17723 a 17982, 18071 a 18393, 18594 a 19866, 56689 a 56696, 56700 e 56712) (Reis e Louro, 1987: 119-121).

37 Trata-se de um serviço encomendado através dos afamados armazéns parisienses Grand Dépôt E. Bourgeois composto pela seguinte forma: o serviço de mesa tem fundo branco, rebordos espiralados (forma Torse), cercadura com motivo padronizado e filete dourado, com monograma coroado da rainha D. Maria Pia; o serviço de sobremesa (os açucareiros eram da Haviland) foi pintado pelo afamado artista Muville com representações de peixes, de aves, de flores e de pintainhos, com o mesmo monograma coroado, os rebordos em dourado nos pratos e nas travessas. É exemplificativo do quanto a monarca escolhia com precisão um conjunto para ser usado num determinado ambiente e decoração mais informal, sem descurar o requinte (APNA, 1911: 1462v. a 1463) (Reis e Louro, 1987: 118). Um lote foi vendido na leiloeira São Domingos, na cidade do Porto, em abril de 2015; o segundo na leiloeira Almeida \& Monteiro, em Lisboa, em maio do mesmo ano; o terceiro na Cabral Moncada em junho de 2019. Este último foi adquirido pelo estado para integrar o acervo do Palácio Nacional da Ajuda (PNA, inv. 22062 a 22293, 58030 a 58035, 55497 e 58363$)$. 


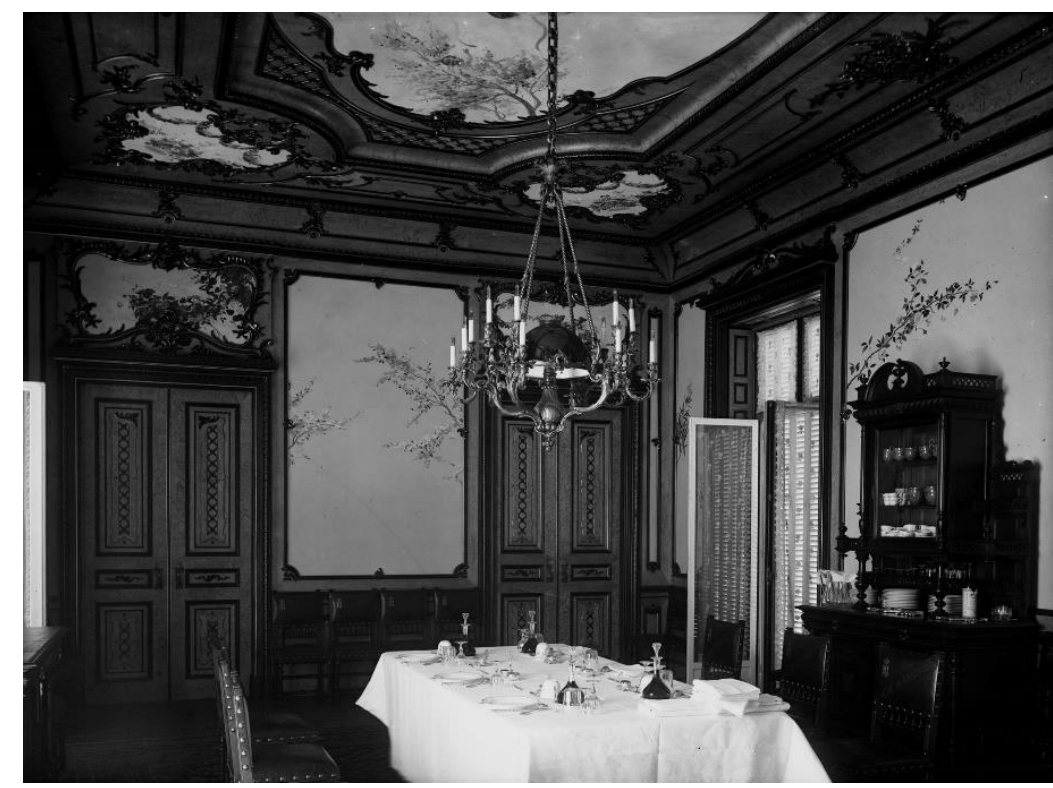

Fig. 10 - Casa de Jantar, provavelmente em 1896, fotografada para o artigo de Henrique Marques. Podemos observar no guarda-prata as chávenas Vista Alegre e Sèvres. Na mesa estão chávenas da Vista Alegre, os dois saleiros da Baixela Veyrat e o serviço de mesa em vidro que está hoje no Palácio Nacional de Sintra (PNS, inv. PNS4659 a PNS5368). Fotografia de autor desconhecido, sem data. Arquivo da Câmara Municipal de Lisboa, núcleo fotográfico, cota: NEG001071.

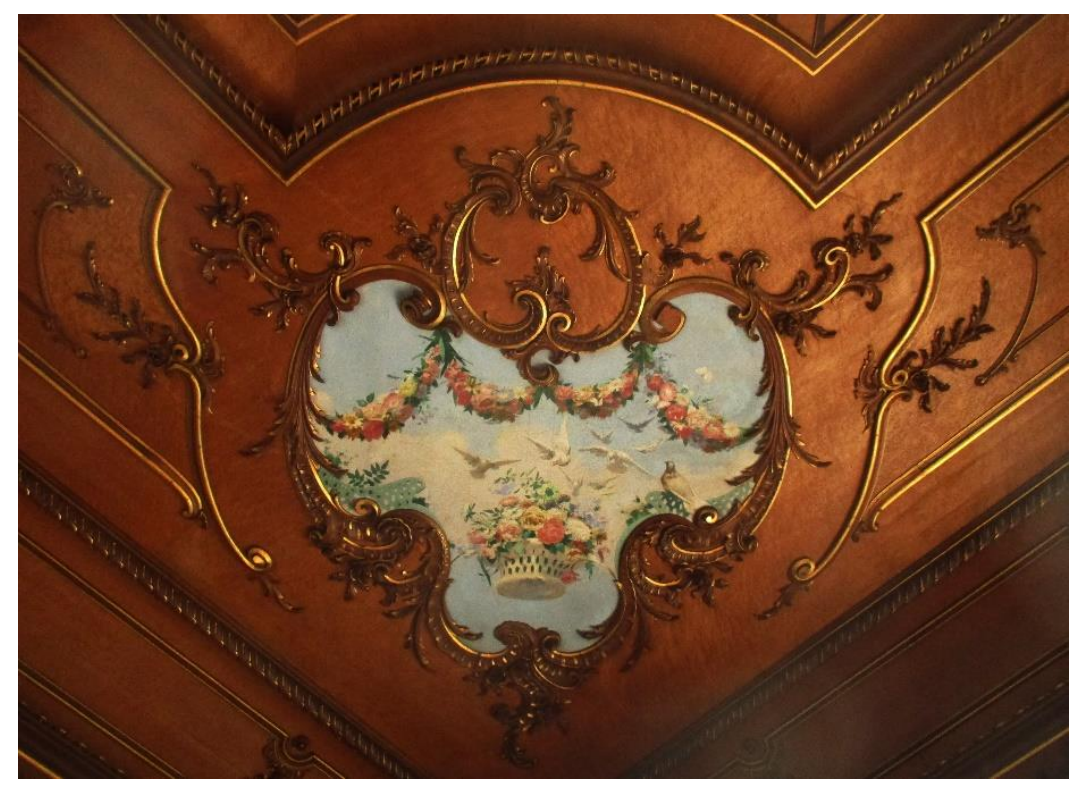

Fig. 11 - Casa de Jantar, pormenor de um dos medalhões nos cantos das cambotas, com pintura de António Ramalho. Fotografia do autor, 8 de novembro de 2018. 


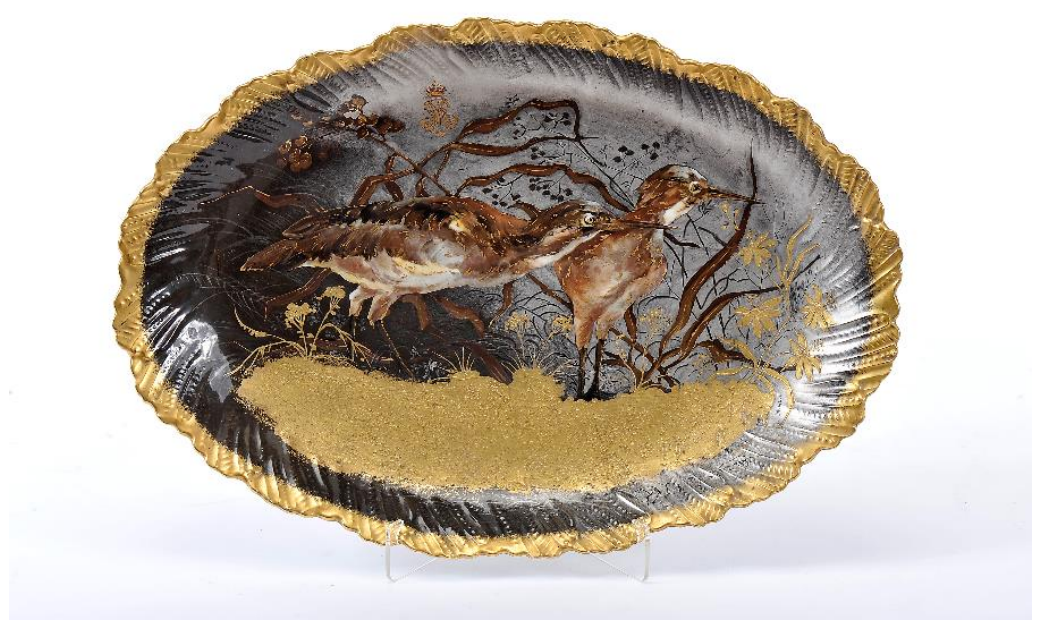

Fig. 12 - Travessa, de um total de oito, do serviço de sobremesa Laviolette, lote 438 do leilão presencial N. ${ }^{\circ}$ 200, datado de 4 de Junho de 2019. Cortesia da Cabral Moncada Leilões / Vasco Cunha Monteiro 2019.

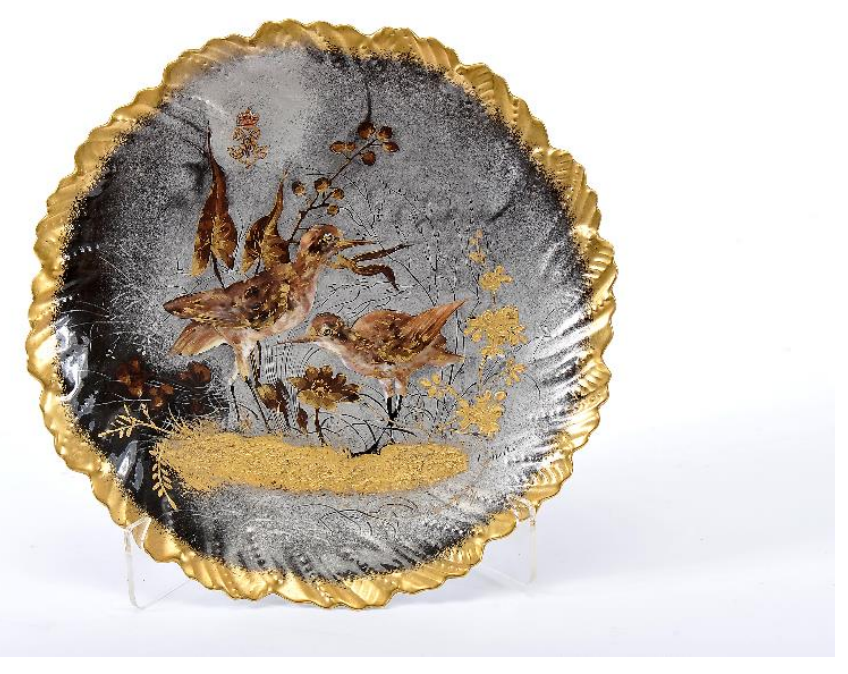

Fig. 13 - Prato do serviço de sobremesa Laviolette, lote 437 do leilão presencial N. ${ }^{\circ}$ 200, datado de 4 de Junho de 2019. Cortesia da Cabral Moncada Leilões / Vasco Cunha Monteiro 2019.

A Escada interior era iluminada por três candeeiros para petróleo de parede e por um de parede para luz elétrica com a respetiva tulipa ${ }^{38}$ (APNA, sem data: 66-67).

\footnotetext{
${ }^{38}$ Pode ser o mesmo que ainda se encontra na caixa de escadas do edifício. É um braço em metal dourado para gás e que foi posteriormente adaptado para eletricidade.
} 
O inventário do então denominado Andar Nobre, habitado pela família real, começou pelo corredor onde estavam dois armários e um guarda-fato. A luz artificial era assegurada por dois candeeiros para petróleo de parede e por duas tulipas suspensas para eletricidade. O Primeiro Quarto era para dormir e tinha uma tulipa para lâmpada elétrica. O Segundo Quarto era também para dormir e tinha dois candeeiros em metal dourado. Não sabemos a quem estava (m) destinado (s) estes espaços (APNA, sem data: 68-75) ${ }^{39}$.

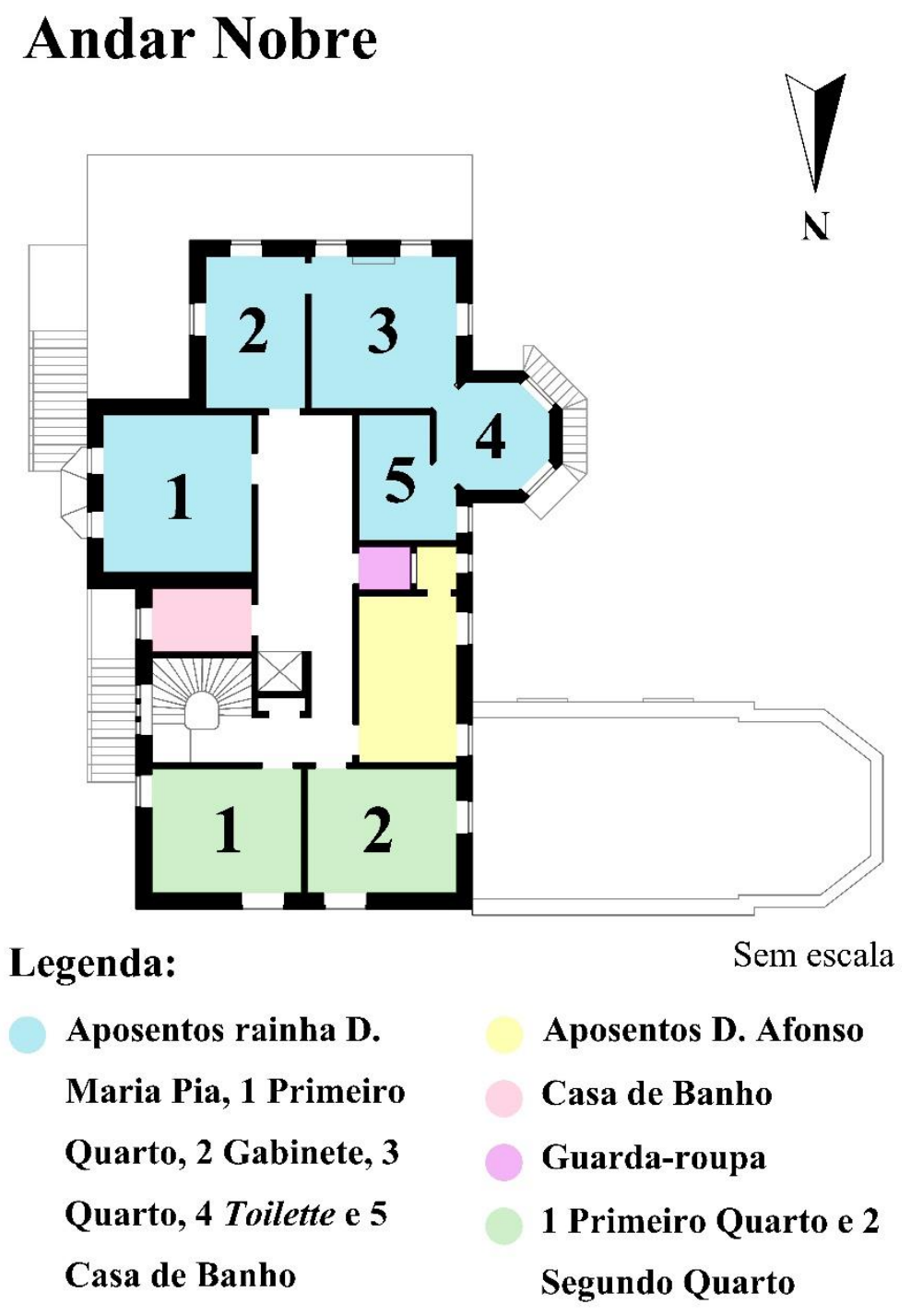

Fig. 14 - Planta do Andar Nobre realizada pelo autor em formato digital.

\footnotetext{
${ }^{39}$ Poderiam ser os dos netos, do príncipe real D. Luís Filipe e do infante D. Manuel.
} 
O Quarto de Sua Alteza era o quarto de dormir do infante D. Afonso, segundo filho da rainha. Do tecto estava suspenso um lustre em ferro preto e ornatos em cobre para cinco tulipas e respetivas lâmpadas elétricas, provavelmente o adquirido na $R$. Ditmar. Contíguo a este havia o Quarto de lavar de Sua Alteza e que era uma instalação sanitária, iluminada por uma tulipa e lâmpada elétrica. A mesma fonte de luz foi empregue na instalação sanitária do respetivo piso (APNA, sem data: 76-83).

No mesmo pavimento os aposentos da rainha D. Maria Pia tinham início no Primeiro quarto dos aposentos de Sua Magestade que continha uma secretária Louis $X V$, mesas, bastidor para bordar e material para pintura, aguarela e desenho. Poderá tratar-se do seu atelier ${ }^{40}$. O Gabinete continha uma pequena secretaria Vernis Martin acharoada de verde (PNA, inv. 2962) ${ }^{41}$, duas mesas e uma étagère A iluminação elétrica era assegurada por um lustre de metal dourado em forma de ovo (PNP, inv. PNP1125) (APNA, 1912, 3398 a 3398v. $)^{42}$, adquirido na Gagneau, e um candeeiro de mesa com quebra-luz de folha pintada. Tinha também um castiçal de prata da Baixella, com arandela de vidro, suporte metálico e abat-jour em papel cor-de-rosa. No inventário não mencionam a qual baixela pertenceria o castiçal ${ }^{43}$, mas poderá ser um, de um total de vinte e três, que fazem parte da denominada Baixela Germain (PNA, inv. 5326 a 5342; MNAA, inv. 1928 a 1931 e 1934 a 1935) (APNA, 1910-1911: 2492v.). A presença desta peça setecentista como que enfatiza ainda mais esse período histórico, integrada com a restante decoração

\footnotetext{
${ }^{40} \mathrm{Na}$ Ajuda e no Paço de Queluz a monarca também tinha os seus ateliers.

${ }^{41}$ Peça da autoria de Sormani Veuve Paul et Fils de Paris (Andrade, 2009: 218-222) (APNA, 1912: 3535v. a 3537v.). No mesmo fornecedor adquiriu, em 1888, o bonheur LXV vernis martin ou bonheur-du-jour à abattant actualmente com o número de inventário 2100 do Palácio Nacional da Ajuda. Cf. (Andrade, 2009: 210-213). Identificado por nós no arrolamento (APNA, 1912: 3534v. a 3535v.).

${ }^{42}$ Identificado por nós no decurso desta investigação.

${ }^{43}$ A baixela Veyrat, dita do casamento do rei D. Luís e de D. Maria Pia na documentação coeva, não tem castiçais, mas, sim, dois candelabros para 7 lumes cada um (APNA, 1911: 1265 a 1277v.) (PNA, inv. 9635 a 9828,50702 a 50755 e 64849$)$.
} 
e mobiliário de fabrico moderno inspirado nessa época ${ }^{44}$. No Quarto da cama de Sua Magestade Rainha o mobiliário era ao gosto de Louis XV. A iluminação elétrica era assegurada pelo braço em forma de ramo e flor em cristal de Veneza e pelo lustre em bronze, para quatro lumes e quebra-luz em forma de ovo, adquiridos na Gagneau. O Toilette de Sua Magestade continha mobiliário Louis $X V$ e iluminado por um anjinho de madeira, com fita suspenso do tecto, e por dois braços com tulipas. Estes deveriam ladear um dos móveis e podem ter sido os adquiridos na R. Ditmar em Roma. O mesmo uso de velas foi seguido neste espaço com a presença de um castiçal da Baixela Germain (MNAA, inv. 1928 a 1931 e 1934 a 1935), já referida, e por um par de castiçais em prata, com as armas do rei D. João VI (1767-1826) e que pertenceram ao Real Thesouro (PNM, inv. PNM7347 a PNM7348). Este espaço comunica com a antiga Casa de Banho e que continha: um guardafato Louis $X V$, retrete, lavatório, bidet e demais objectos para a higiene diária. Tinha duas tulipas e lâmpadas elétricas. A mesma fonte de luz iluminava o Guarda-Roupa, conjuntamente com um candeeiro para petróleo de parede. Aqui terminou o inventário do Andar Nobre e em seguida descreveu-se o andar superior, provavelmente reservado aos elementos da corte mais próximos à família real (APNA, sem data: 84-119).

\footnotetext{
${ }^{44}$ Além de fazer referência a um dos mais célebres ourives franceses: François-Thomas Germain (17261791) ourives do rei de França e fornecedor de várias casas reais europeias, entre elas a portuguesa e detentora de um significativo acervo artístico de sua autoria.
} 


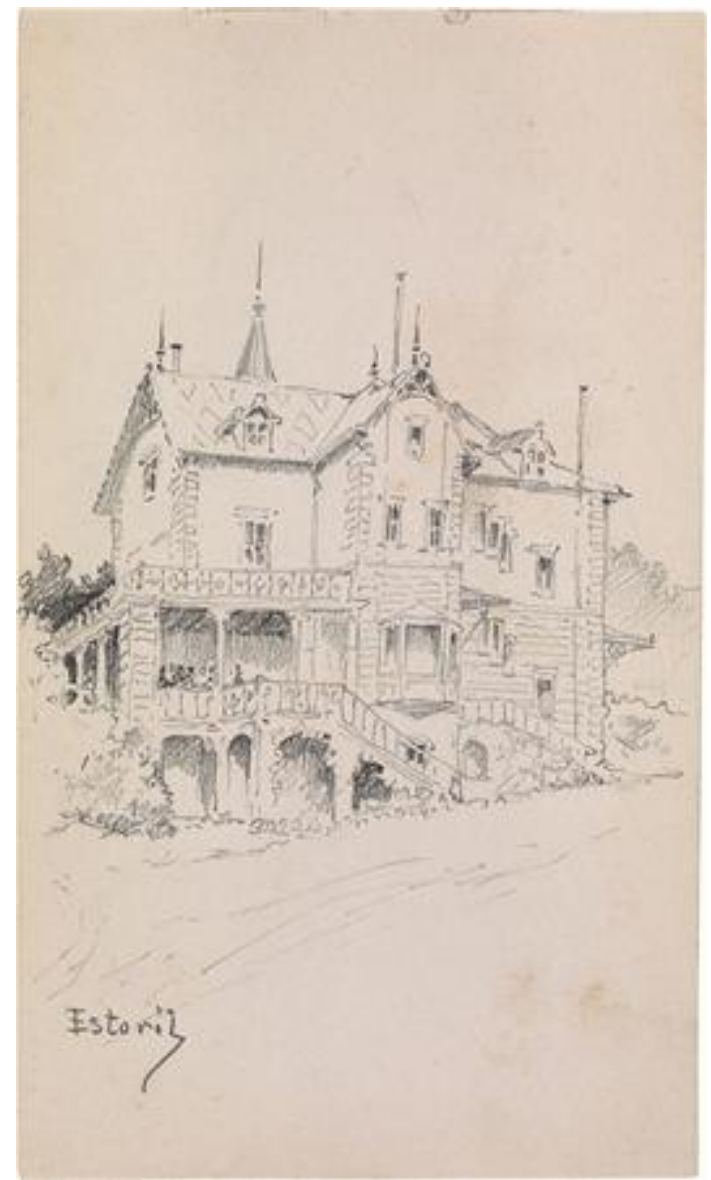

Fig. 15 - Desenho datado de 1898 do Chalet da autoria da rainha D. Maria Pia (PNA, inv. 58277/3). Direção-Geral do Património Cultural / Arquivo de Documentação Fotográfica (DGPC/ADF). 


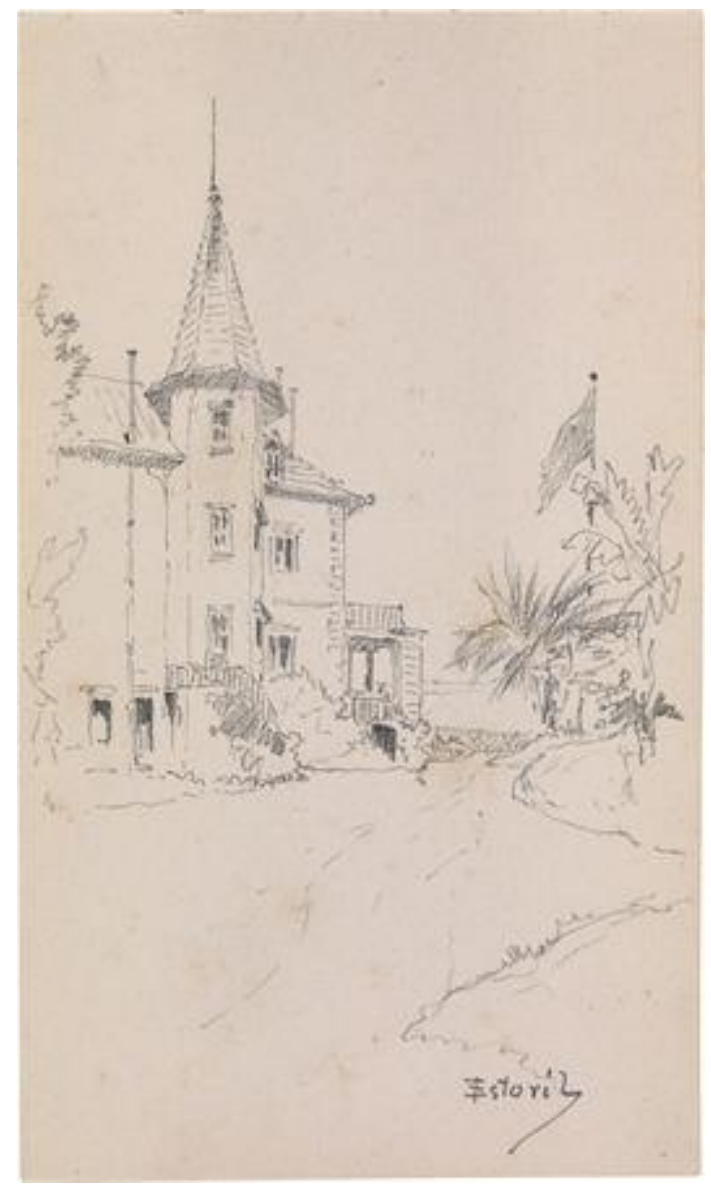

Fig. 16 - Desenho datado de 1898 do Chalet da autoria da rainha D. Maria Pia (PNA, inv. 58277/4). Direção-Geral do Património Cultural / Arquivo de Documentação Fotográfica (DGPC/ADF).

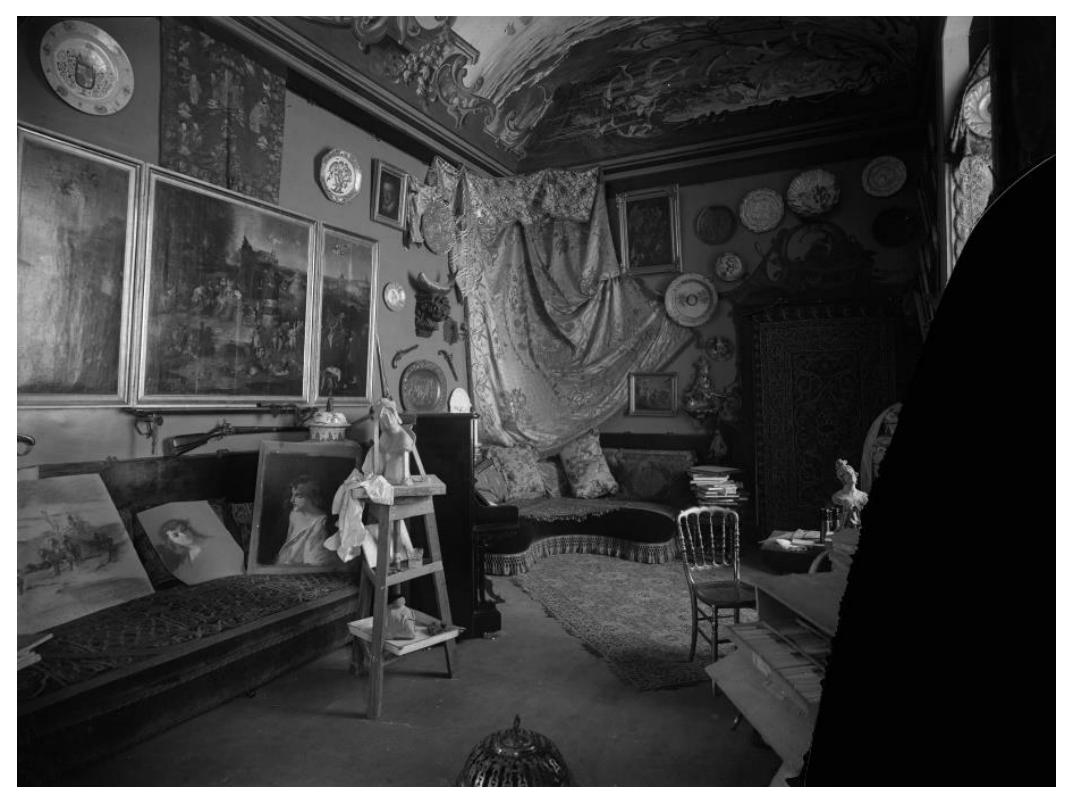

Fig. 17 - Atelier do rei D. Carlos no Paço das Necessidades, fotografado para um artigo de Alfredo Guimarães publicado, em 1899, no número 3 da revista Brasil-Portugal. Identificado por nós nesta investigação. Podemos observar como a Família Real tinha um verdadeiro apreço pelo mar e pelas artes, expresso no teto. No lado esquerdo está a obra Tentações de Santo Antão (MNAA, inv. 1498 Pint) do pintor holandês Jheronymus Bosch (c. 1450-1516). Fotografia de autor desconhecido, sem data. Arquivo da Câmara Municipal de Lisboa, núcleo fotográfico, cota: NEG000330. 
No Corredor do ultimo pavimento havia um guarda-fatos e uma cómoda. Era iluminado por dois candeeiros para petróleo de parede e por uma tulipa com lâmpada elétrica. Os restantes espaços eram o Primeiro quarto do ultimo pavimento, o Segundo quarto, o Terceiro quarto, o Quarto quarto, a Retrete, a Casa de banho, os Aposentos do Particular de Sua Magestade, o Segundo quarto, o Quarto do Ajudante de Sua Alteza e a Casa de banho eram todos iluminados por tulipas e respetivas lâmpadas elétricas (APNA, sem data: 120151).

O Pavimento terreo era reservado às áreas de serviço e aos quartos dos criados internos. A iluminação elétrica estava circunscrita à Casa de jantar da mesa da familia, à Rouparia, aos Corredores (onde estava o telefone e o quadro elétrico das campainhas dos pisos superiores), à Mantieiria e à Cosinha $e$ dispensa com tulipas para lâmpadas suspensas. Na Cosinha e dispensa também havia braços para eletricidade e candeeiros para petróleo de parede. Estes últimos também iluminavam os Corredores e a Mantieiria. Na Ucharia não havia iluminação artificial. O Quarto do moço d'ordens, o Quarto do creado do Ajudante de S. A., o Quarto do moço de sala, o Quarto dos cozinheiros, o Quarto do moço de meza e o Quarto de valet-pied tinham castiçais e palmatórias para velas. Nos Quartos de criados dos quartos também não foram descritas as fontes para iluminação (APNA, sem data: 158-177).

A Cosinha e dispensa continham toda a parafernália necessária para a confeção de comida. Próxima a estes espaços estava a Mantieiria onde estava o restante serviço de Haviland e Laviolette, já aludidos (APNA, sem data: 184-190).

A Casa dos candieiros também estava próxima à cozinha, por causa da proximidade ao fogo, à água corrente para limpeza e à receção dos combustíveis. A autonomia prendia-se com o facto da nocividade dos 
produtos usados: o petróleo, os líquidos para polimento dos metais e outros ${ }^{45}$. Além de que a manutenção regular era necessária que fosse feita à parte, como o encher dos reservatórios e o aparar das torcidas, evitando assim sujar as superfícies e a entrar em contacto com os alimentos.

Neste espaço foram elencados todos os exemplares que estavam então em uso no Chalet, sem mencionarem a quem pertenciam e onde eram regularmente usados. Deste conjunto todo os que, aparentemente, pertenceram à família real foram o (s):

- Um dos dois candeeiros para petróleo comprados em 1893 na Gagneau. Ambos ao gosto Louis XV, com queimador Duplex da Evered \& C. ${ }^{\boldsymbol{o}}$, globos aos redemoinhos da Baccarat e arrolados na Ajuda (PNA, inv. 2070) (Fevereiro, 2018: 62-64);

- Provavelmente a Lamparina da signora comprada em 1893 na $R$. Ditmar. O candeeiro foi depois para o Paço de Sintra e entregue ao ministro de Itália em Lisboa para ser devolvido à rainha no exílio (Fevereiro, 2018: 61-62);

- O candeeiro modérateur bronze argenté da Gagneau com as armas dos reis de Portugal (PNA, inv. 853);

- 1 candeeiro para azeite em metal branco e com monograma real. Poderá ser o que pertenceu à rainha $\mathrm{D}$. Maria $\mathrm{Pia}^{46}$ ou o de D. Afonso (PNA, inv. 42049) ambos modérateur bronze argenté e da Gagneau (Fevereiro, 2018: 48-49);

\footnotetext{
${ }^{45}$ Em todos os paços reais havia tabuleiros, escovilhões, panos, tesouras próprias e outros apetrechos para a manutenção dos candeeiros para óleo vegetal, petróleo e gás.

46 O candeeiro não foi arrolado no Paço da Ajuda, mas foi dado como desaparecido e seguido de um inquérito sobre o seu paradeiro aos empregados do Chalet do Estoril. Poderá ser o mesmo que apareceu no mercado leiloeiro, na parisiense Coutau-Bégarie, sendo o lote 229 do leilão Noblesse \& Royauté do dia 15 de novembro de 2019. Queremos agradecer a Eduardo Alves Marques nos ter indicado que este exemplar ia a leilão.
} 
- 1 candeeiro para azeite de metal branco lavrado ${ }^{47}$;

- 1 candeeiro para azeite em latão. A descrição é muito sucinta e no Paço da Ajuda foram arrolados diversos exemplares deste tipo em metal dourado $^{48}$;

- 1 dos modérateurs em faiança denominada de Delft adquiridos em 1893 na Gagneau;

- 9 candeeiros para azeite de vidro branco ${ }^{49}$.

${ }^{47}$ Pode ser um modérateur em metal prateado da Gagneau que se encontra desaparecido (Fevereiro, 2018: 160).

${ }^{48}$ Poderá ser um modérateur espiralado em metal amarelo da Gagneau e que não foi localizado (Fevereiro, 2018: 175).

${ }^{49}$ São, possivelmente, modérateurs que fizeram parte de um vasto conjunto, com o corpo principal em vidro facetado, usados em vários paços na altura dos arrolamentos (Fevereiro, 2018: 175-176). 


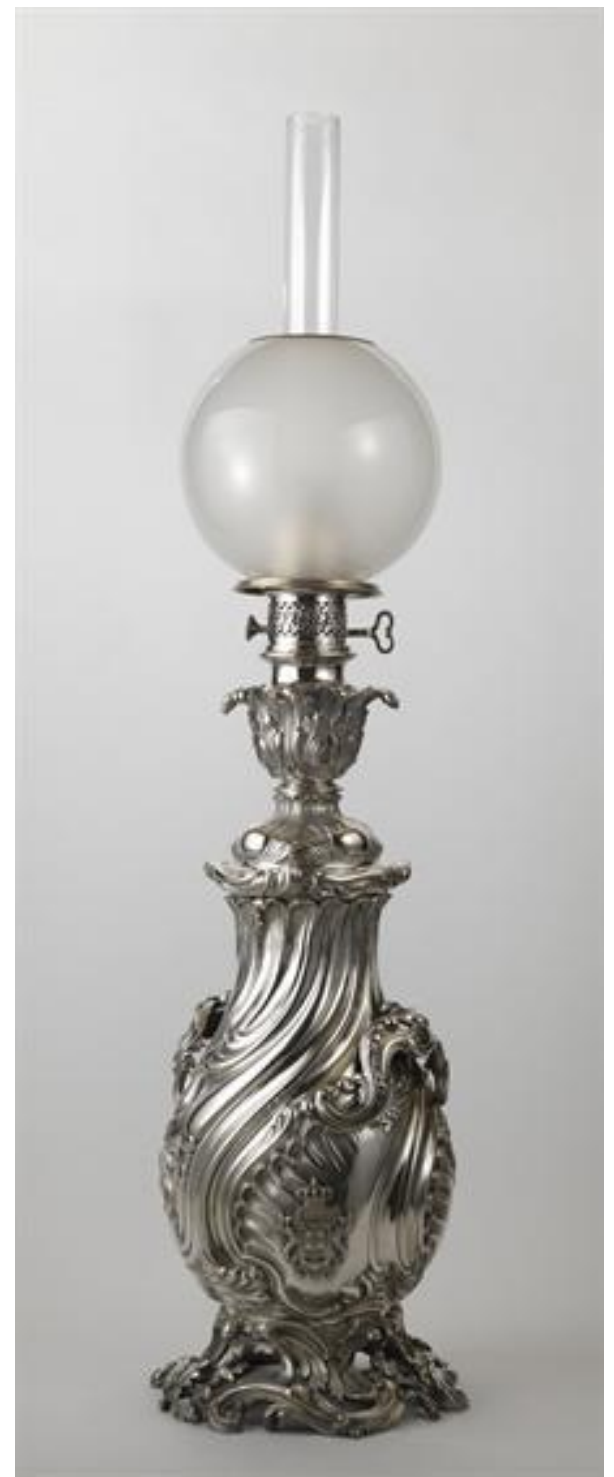

Fig. 18 - Candeeiro modérateur da Gagneau com as armas dos reis de Portugal. Datação: 1880 a 1900. Dimensões: $66 \times 24 \varnothing \mathrm{cm}$, sem quebra-luz nem chaminé (PNA, inv. 853). Fotografia de Luísa Oliveira (PNA 47894 DIG), 2012, Direção-Geral do Património Cultural / Arquivo de Documentação Fotográfica (DGPC/ADF). 


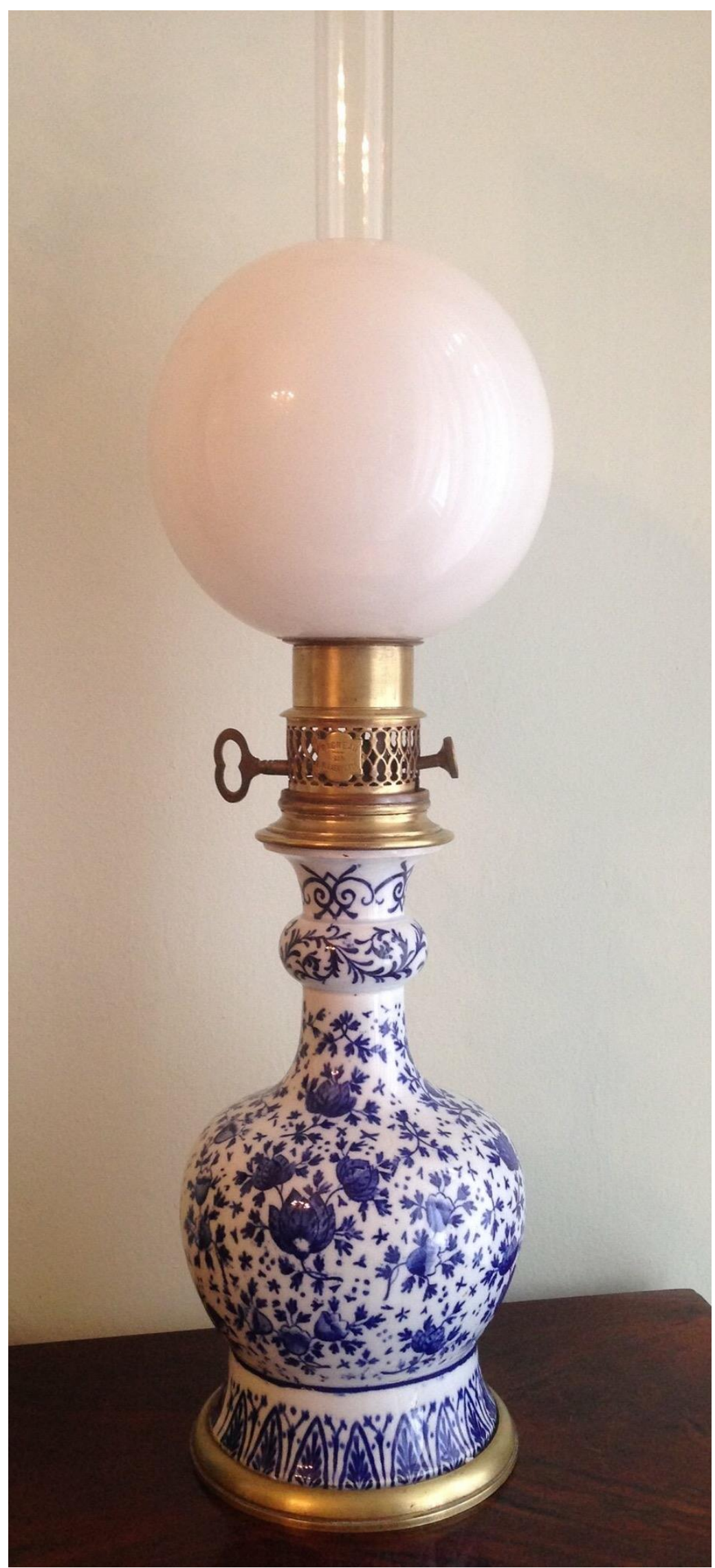

Fig. 19 - Candeeiro modérateur da Gagneau com peça em faiança dita de Delft. Datação: 1880 a 1900. Dimensões: 44x16Ø cm, sem quebra-luz nem chaminé. Coleção e fotografia Rusvai Lazslo. 
Os restantes candeeiros não sabemos se eram propriedade da família real, por isso, preferimos abordá-los separadamente.

Os exemplares para petróleo inventariados foram o (s):

- 6 reservatórios de folha com queimadores N. 14 e chaminés para a iluminação externa;

- 1 candeeiro Vulkan Universal Brenner da Wild \& Wessel ${ }^{50}$;

- 1 candeeiro da Wild \& Wessel, modelo 1849 de zinco ao gosto maneirista (PNS, inv. PNS3467 ou PNP, inv. PNP662) (Fevereiro, 2018: 70$71)$;

- 5 candeeiros de ferro com queimadores no tamanho 10, globos e chaminés;

- 17 candeeiros com queimadores no tamanho 8, com chaminés e globos.

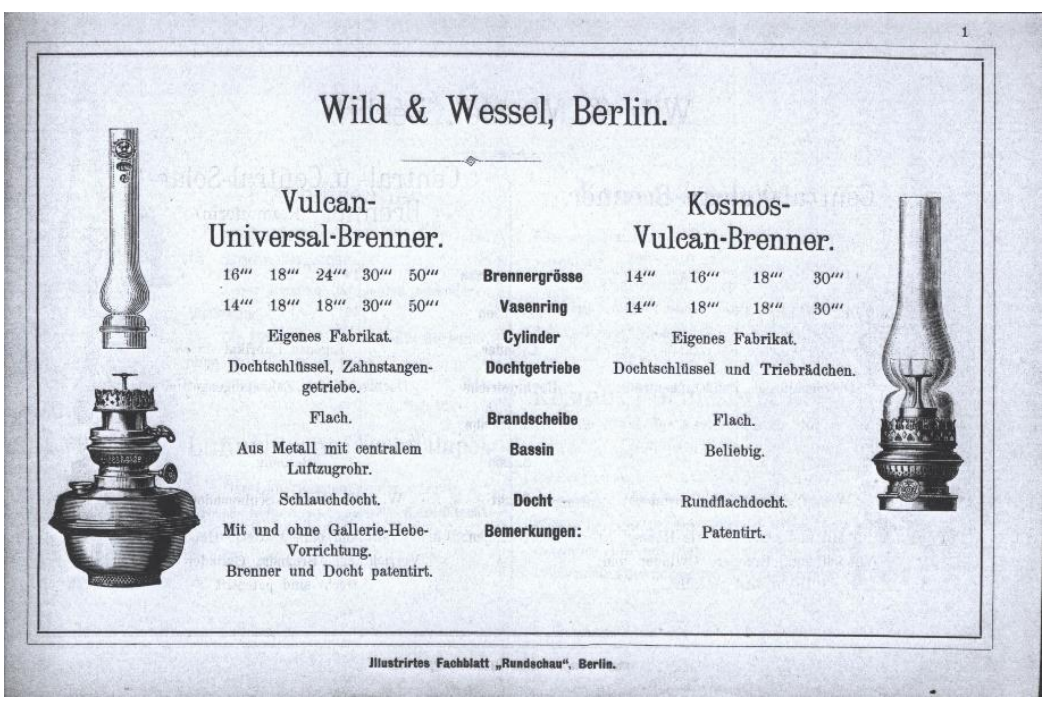

Fig. 20 - Gama Vulkan Universal Brenner e Kosmos-Vulkan da Wild \& Wessel (Goldberg, 1893: 1).

\footnotetext{
${ }^{50}$ A fábrica era a única a designar por Vulkan parte dos seus queimadores, subentendendo, assim, uma maior luminosidade (Goldberg, 1893: 1). Este reservatório também foi exportado para o retalhista/fabricante londrino S. P. Catterson \& Sons, Ltd. e designado por Globe.
} 
As peças para iluminação elétrica são:

- 2 braços de latão dobráveis para parede (podem ser os da $R$. Ditmar);

- 4 placas de bronze dourado e podem ser as adquiridas em 1893 na Gagneau ${ }^{51}$.

Constatamos aqui que os candeeiros para azeite e para petróleo estavam concentrados nestas divisões, como acontecia nos outros paços (APNA, sem data: 178-183). Tal facto deve-se à sua não utilização e por isso eram arrecadados, limpos, as torcidas aparadas e os reservatórios esvaziados. Em contraponto, constata-se também aqui que os candeeiros elétricos geralmente ficavam in situ, o que favorece a nossa investigação e o cotejar com os documentos coetâneos.

${ }^{51}$ No arrolamento da Ajuda foram descritas quatro serpentinas de parede cada uma para 4 lumes e outras tantas para 2 lumes cada (poderão ser as compradas na R. Ditmar), as quais não foram ainda localizadas. 


\section{CONCLUSÕES}

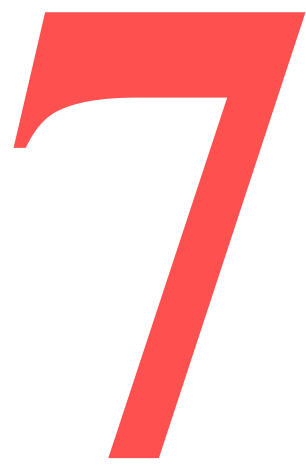

No início da década de 90 do século XIX a época da renascença, da renascença germânica, do maneirismo, dos reinados de Louis XIII, XIV, XV, XVI, a par de um crescente desenvolvimento de peças com um desenho depurado, foram fonte de inspiração nas artes decorativas. Estas foram seguidas no mobiliário, nos serviços de mesa, nas peças decorativas, nos tecidos e na luminária, entre outras criações. Nesta última categoria é sintomática a persistência de modelos do passado, onde eram usadas velas, copiados para a eletricidade e usados com quebra-luzes em tecido. Noutras peças a fonte de luz proporcionou novas formas onde se empregaram peças em vidro e em cerâmica especificamente desenhadas para a indústria da iluminação. A rainha D. Maria Pia foi sempre sensível ao que estava a acontecer e assimilou-o de acordo com o seu gosto. Esta propensão constatase aquando da aquisição do então Chalet Longa Vista, no Monte Estoril, e que passou a ser denominado por Chalet ou Paço do Estoril ao ordenar diversas obras e ao escolher criteriosamente o seu recheio.

O interior do edifício original foi parcialmente modificado e construiu-se a nova Casa de Jantar com capacidade suficiente para comportar a família real, a sua corte e convidados consoante a ocasião. Este espaço foi forrado parietalmente e no tecto a boiseries ao gosto de Louis $X V$, complementado por pinturas polícromas, e é o mais rico do ponto de vista decorativo. Nos restantes realizaram-se estuques e mantiveram-se os existentes com um desenho simples e sofisticado. 
O seu recheio móvel constituiu uma oportunidade para levar a efeito um programa decorativo consistente em todas as divisões, para o qual contribuiu a sua escala e o número de compartimentos ser menor em comparação com os do Paço da Ajuda e os de Sintra, onde também habitava a rainha respetivamente de dezembro a maio (inverno e primavera) e de junho a agosto (meses de vilegiatura). Os meses de setembro a novembro eram geralmente passados no Estoril para a época balnear, embora não cumprisse de forma rigorosa esta cronologia.

No seu interior havia mobiliário antigo, outro recente e o restante adquirido propositadamente na altura das remodelações. Este foi deliberadamente escolhido para determinados quartos de acordo com a sua função e estilo. Temos assim a predominância do gosto Louis $X V$ na Primeira Sala, na Segunda Sala e na Salinha Oitavada do Primeiro Pavimento, que eram os espaços de estar e de carácter social. Em contra-ponto, e no mesmo piso, os aposentos do rei foram decorados ao gosto da renascença francesa. Na Sala d'entrada optou-se por um mobiliário escuro, provavelmente D. João V de acordo com a leitura, e na Sala de espera por outro em dourado Louis XV. No andar nobre este ficou circunscrito aos aposentos da rainha, integrado com outro outro de gosto eclético e moderno, evidenciando assim uma certa feminilidade. Nos aposentos de D. Afonso optou-se por mobiliário em tons escuros.

A mesma lógica foi seguida com a luminária e que foi disposta de acordo com a sua função, a sua incidência de luz e o seu desenho num programa decorativo específico. Esta tem sido identificada no cotejamento do referido inventário com os recibos de compras, os arrolamentos judiciais republicanos, o acervo existente nas instituições museológicas e noutras afetas ao estado português. O que podemos constatar é que a rainha escolheu nas lojas mais selectas diferentes tipologias, as tendências mais recentes e os quebra-luzes em consonância. Todavia uma parte foi descrita no inventário, mas naquele período, por isso, temos de compreender que os objectos são móveis e que circulavam entre os paços conforme a necessidade. 
A luminária do Chalet do Estoril testemunha a transição das fontes de iluminação a chama para a eletricidade, que eram simultaneamente usadas na mesma divisão.

O Chalet do Estoril espelha as tendências decorativas de finais do século XIX, em que referências culturais portuguesas foram conjugadas com outras internacionais, mas é sobretudo um exercício em que a apetência para a decoração e o interesse pela arquitetura $^{52}$ da rainha D. Maria Pia foram proficuamente desenvolvidas.

\footnotetext{
${ }^{52} \mathrm{Na}$ nossa investigação temos vindo a constatar o interesse da rainha pela arquitetura, nomeadamente a presença de vários números da publicação quinzenal portuguesa A Construcção Moderna (p. 1900 a 1919), um álbum com o projeto do Castel Béranger do arquiteto francês Hector Guimard (1867-1942), um dos primeiros edifícios Arte Nova em Paris (PNA, inv. 53792), várias obras dedicadas à decoração, nomeadamente a Arte Nova (PNA, inv. 53889 e 59510), projeto de um Chalet da autoria de António Maria Paixão (1866-?) e o projeto para a remodelação da Muralha do Carmo (houve, pelo menos, dois realizados pelos arquitetos Álvaro Augusto Machado (1874-1944) e Leonel Gaia (1868-1941) no início do século XX, tendo sido o de este último autor o seguido) (APNA, 1911: 292, 342v, 997v e 999v) (APNA, 1912: 2546v).
} 
Album Açoriano (1903). Album Açoriano. Lisboa: Oliveira \& Baptista.

\section{Bibliografia}

Andrade, Maria do Carmo Rebello de, "Paul Sormani e o estilo Luís XV. Os móveis preferidos da rainha D. Maria Pia," Revista de Artes Decorativas, 3 (2009): 193-230.

Beziel \& Ribot (1900-1910). Beziel \& Ribot, Bronzes d'Éclairage Electricité. Manufacture de bronzes et d'appareils d'éclairage par l'electricité et le gaz. Paris: Beziel \& Ribot.

Correia, Cristina Neiva, "Quelques petits souvenirs de Sèvres. Elementos para o estudo do acervo cerâmico do Palácio Nacional da Ajuda," Revista de Artes Decorativas, 2 (2008): 85-122.

Fevereiro, António Cota (2019). A Evolução do Candeeiro no Século XIX, tipologias e usos. In Pessoa, Ana e Coimbra, Artur (coor.), Actas do V Colóquio Internacional, A Casa Senhorial: Anatomia dos Interiores. Fafe: Câmara Municipal de Fafe, 363-388

Fevereiro, António Cota (2018). Iluminação da Casa Real Portuguesa. Os Candeeiros do Palácio Nacional da Ajuda. Oeiras: Mazu Press.

Fevereiro, António Cota (2012). Genealogia, dados biográficos e obra de arquitetos, artistas e construtores civis portugueses do século XIX e XX. In Machado, José Carlos Soares (dir.), Raízes e Memórias (29). Lisboa: Associação Portuguesa de Genealogia, 241-292. 
Goldberg, Jacques (1893). Die Deutsche Petroleum-Lampe in Wort und Bild. Berlim: Rundschau.

Maple \& Co. (1889). Maple et Cie, Catalogue illustré d'ameublements, Fournisseurs de Sa Majesté la Reine d'Angleterre. Tottenham Court Road. Londres: Maple \& Co.

Monte-Cristo (Eugenio Rodríguez Ruiz de la Escalera) e Franzen y Nisser, Christian (1898). Los Salones de Madrid. Madrid: El Álbum Nacional.

Montesinos, Fernando (2019). A Royal Lunch, Entre a evocação e a reconstituição. In Ferro, Inês e Pereira, António Nunes (coord.), A Royal Lunch. A visita a Sintra da Rainha Alexandra do Reino Unido. 24 de março de 1905. Sintra: Parques de Sintra - Monte da Lua, S.A, 76-91.

Ramos, Rui Jorge Garcia (2010). A Casa - Arquitectura e Projecto Doméstico Na Primeira Metade Do Século XX Português. Porto: Faculdade de Arquitetura da Universidade do Porto.

Reis, Ana Maria Batalha e Louro, Francisco de Carvalho (1987). Porcelana europeia reservas do Palácio Nacional da Ajuda. Lisboa: Fundação Calouste Gulbenkian.

\section{Arquivo Nacional da Torre do Tombo}

ANTT, Casa Real, Caixa 7008.

\section{Arquivo Palácio Nacional da Ajuda}

APNA, (sem data), Inventário do Real Chalet Estoril.

APNA, (1911-1914), Inventário Judicial do Palácio da Ajuda.

APNA, (1910-1911), Inventário Judicial do Palácio das Necessidades.

\section{Periódicos}

Costa Campos, Alfredo Maria da, "Sanatorio Sant'Anna (Parede), Architecto, sr. Rozendo Carvalheira," A Architectura Portugueza, Ano I (9), setembro 1908, 33-35.

Marques, Henrique, “O Chalet da Rainha D. Maria Pia, no Estoril,” Branco e Negro: Semanario Illustrado, Ano I (31), 1 novembro 1896, 74-75. 


\section{Referências de Internet}

"Plantas da vila no Estoril de Sua Majestade a rainha a senhora D. Maria Pia,", Arquivo Nacional da Torre do Tombo, última modificação fevereiro, 4, 2015, Acedido maio, 19, 2020, https://digitarq.arquivos.pt/details?id=4644229.

"Casa da Rainha Dona Maria Pia / Vila Maria Pia," Teresa Leonor Magalhães Vale, Maria Ferreira e Sandra Costa, SIPA - Sistema de Informação para o Património Arquitetónico, Acedido maio, 19, 2020, http://www.monumentos.gov.pt/Site/APP_PagesUser/SIPA.aspx?id=9403. 